\title{
EVALUATING LOGISTICS VILLAGES IN TURKEY USING HYBRID IMPROVED FUZZY SWARA (IMF SWARA) AND FUZZY MABAC TECHNIQUES
}

\author{
Sarfaraz HASHEMKHANI ZOLFANI ${ }^{1^{*}}$, Ömer Faruk GÖRÇÜN², \\ Hande KÜÇÜKÖNDER ${ }^{3}$
${ }^{1}$ School of Engineering, Catholic University of the North, Larrondo 1281, Coquimbo, Chile
${ }^{2}$ Faculty of Business, Kadir Has University, Cibaly, Fatih Istanbul, Turkey
${ }^{3}$ Faculty of Economics, Bartin University, Merkez, Bartin, Turkey

Received 05 May 2021; accepted 03 November 2021

\begin{abstract}
Positioning in the right location for organizing logistics activities is a determinative factor in the aspect of costs, effectivity, productivity, and performance of these operations carried out by logistics firms. The proper logistics village selection is a crucial, complicated, and time-consuming process for decision-makers who have to make the right and optimal decision on this issue. Decision-makers need a methodological frame with a practical algorithm that can be implemented quickly to solve these decision-making problems. Within this scope, the current paper aims to present an evaluation tool, which provides more reasonable and reliable results for decision-makers to solve the logistics village selection problem that is very complicated and has uncertain conditions based on fuzzy approaches. In this study, we propose the Improved Fuzzy Step-Wise Weight Assessment Ratio Analysis (IMF SWARA), a modified and extended version of the traditional fuzzy Step-Wise Weight Assessment Ratio Analysis (F-SWARA) to identify the criteria weights. Also, we suggest applying the fuzzy Multi-Attributive Border Approximation area Comparison (F-MABAC) technique to determine the preference ratings of the alternatives. This combination has many valuable contributions. For example, it proposes to use a more reliable and consistent evaluation scale based on fuzzy sets. Hence, decision-makers can perform more reliable and reasonable pairwise comparisons by considering this evaluation scale. Besides, it presents a multi-attribute evaluation system based on the identified criteria weights. From this perspective, the proposed model is implemented to evaluate eight different logistics village alternatives with respect to nine selection criteria. According to the analysis results, while A8 is the most appropriate option, C1 Gross National Product (GNP) is the most significant criterion. A comprehensive sensitivity analysis was performed to test the robustness and validation of the proposed model, and the results of the analysis approve the validity and applicability of the proposed model. As a result, the suggested integrated MCDM framework can be applied as a valuable and practical decisionmaking tool to develop new strategies and improve the logistics operations by decision-makers.
\end{abstract}

Keywords: logistics villages, Improved Fuzzy Step-Wise Weight Assessment Ratio Analysis (IMF SWARA), Multi-Attributive Border Approximation Area Comparison (MABAC), multiple criteria decision making (MCDM).

JEL Classification: C04, C44, C63.

*Corresponding author. E-mail: sa.hashemkhani@gmail.com

Copyright @ 2021 The Author(s). Published by Vilnius Gediminas Technical University

This is an Open Access article distributed under the terms of the Creative Commons Attribution License (http://creativecommons. $\mathrm{org} /$ licenses/by/4.0/), which permits unrestricted use, distribution, and reproduction in any medium, provided the original author and source are credited. 


\section{Introduction}

Institutions observing the global trade and logistics industry expect the global logistics market to rapidly grow after 2020 by USD 29.66 billion (ReportLinker, n.d.). These developments in the logistics market may lead to dramatic changes. As a result of these changes, it is a firm expectation that logistics operators may have to develop new logistics strategies to reduce logistics costs and increase productivity and effectiveness. Accordingly, some approaches can provide opportunities to reach these targets, such as increasing operational options, integrating transportation modes, and consolidating cargoes. In this respect, logistics villages are the most crucial instrument to allow opportunities for developing logistics operations.

Changes in consumers' (Unnikrishnan \& Figliozzi, 2020) shopping behavior depending on COVID 19 pandemic have caused significant changes in logistics and supply chain operations. At first, it has led to growing e-commerce rapidly. Delivery services have increased sharply by approximately a percent of 120 in only the USA (Organisation for Economic Co-operation and Development [OECD], 2020). According to Mokhtarian, e-commerce and home delivery changes are likely to significantly impact the job market, transportation sector (Mokhtarian, 2004), and logistics industry. Moreover, its impacts are not limited to developments in the USA. During the first quarter of 2020, online orders were up $70 \%$ yearon-year in Asia-Pacific. In Europe, they were up 50\% on average (OECD, 2020). These kinds of development show that retailing and delivery operations, which can be accepted as the last mile of logistics operations, will have become more critical. Also, expected development shortly is that quick delivery and micro logistics operations will have become more crucial. Retailing operations that can be accepted as the final part of supply chains will have become a determination factor become a struggle among supply chains. On the other hand, increasing service capacity and improving delivery performance expected from supply chains may also cause to increase logistics costs seriously.

Nowadays, carrying out logistics operations with lower logistics costs is essential for surviving a highly competitive business environment. Therefore, logistics operators and companies try to develop new strategies to reach this target. Some concepts such as centralization, consolidation, and increasing the logistics operation alternatives have become more critical. Centralization of logistics operations and material flow in a trial kinds of centers can help to reduce usage in logistics activities.

The high volume of cargoes can be consolidated in these logistics villages. Hence, it can provide other transportation modes, which have low environmental impacts (i.e., railway, freight transportation), low operational unit costs (for instance, maritime transportation), and high effectivity, at a higher level. As these villages are developed to offer joint services to all logistics companies placed in these villages (Tsamboulas \& Kapros, 2003), this concept can help reduce the operational costs of logistics operators and companies. Besides, since companies producing these kinds of services exist in these villages, it can provide some logistics services, which logistic companies cannot make due to the scale economy.

When the advantages are considered, it is expected that being in these logistics villages becomes obligatory for logistics operators and companies to carry out logistics operations at lower costs and higher efficiency levels. Furthermore, there are many options to select a proper logistics village for logistics companies, and this selection process can be affected 
by many variables and conflicting factors. Because of that, it can be accepted as a decisionmaking problem that is very complicated and time-consuming. Decision-makers need a methodological frame to solve these kinds of issues and making optimal decisions.

Regarding developing new strategies and improving logistics operations, the paper aims to present an integrated fuzzy decision-making model to identify the most appropriate logistics village alternative and evaluate the selection criteria affecting the assessment process. For this purpose, the Improved Fuzzy Step-Wise Weight Assessment Ratio Analysis (IMF SWARA) technique, a modified version of the Fuzzy Step-Wise Weight Assessment Ratio Analysis (F SWARA), was implemented to determine the weights of the criteria. In addition, the fuzzy Multi-Attributive Border Approximation Area Comparison (F MABAC) approach was used to identify the preference ratings of the decision alternatives. It is crucial to identify the appropriate and optimum location for the logistics village for creating a low costly, effective, and productive logistics system for almost all stakeholders of logistics chains such as transport operators, 3 PL logistics service providers, and other actors of a supply chain. Hence, the proposed model was applied to solve a real-life decision-making problem, and the obtained results were validated by implementing a comprehensive sensitivity analysis. In this perspective, the current paper's potential contributions and managerial implications can be summarized as follows.

- Identifying the most suitable location for the logistics village can help to improve logistics activities and operations and contribute to reducing risks and operational costs.

- It presents a practical, reliable, and easily applicable algorithm to decision-makers for making right, reasonable decisions.

- It presents the IMF SWARA approach, a more reliable weighting technique, and an improved version of the classical F SWARA technique and proposes a hybrid model by combining this weighting technique with the fuzzy MABAC technique, a novel fuzzy model.

- The IMF SWARA, part of the proposed model, requires fewer computations and pairwise comparisons than other traditional versions of the weighting technique.

- It provides a more flexible evaluation environment that can overcome many complex situations and uncertainties.

- The current paper approves the proposed model's validity, robustness, and applicability by implementing a comprehensive sensitivity analysis.

Within this scope, the proposed integrated fuzzy decision-making approach can help decision-makers responsible for making strategic decisions for making rational and reliable decisions. It can be inspirational for authors who perform future scientific works on this issue.

This paper consists of five main sections: In Introduction, the importance of the topic, research questions, and the concept of logistics village have been summarized. In Section 1, a comprehensive literature review was performed, and previous studies related to the literature were examined. While the suggested fuzzy multi-criteria decision-making (MCDM) model is introduced in Section 2, a numerical analysis was performed in Section 3. A comprehensive sensitivity analysis was performed in the fourth section to validate the proposed model, and the obtained results are discussed in Section 5, and it has been concluded. 


\section{Literature review}

The selection of the proper logistics village is essential for logistics operators. This selection can primarily determine the companies' competitive power. This selection determines whether a logistics company can survive in a highly competitive business environment. It is seen that this kind of selection has vital importance for logistics companies.

When the literature related to logistics or freight villages is evaluated, it is seen that there are many studies in the literature. Due to its crucial importance and advantages for both the logistics industry other industries, many studies are addressing different issues on logistics villages including, location selection (Kumar \& Anbanandam, 2019; Kayikci, 2010), sustainability for LV (Ozceylan et al., 2016), comparison of the logistics villages established in Turkey and E.U. countries (Peker et al., 2016; Hamamcioğglu \& Oguztimur, 2017), the importance of logistics villages (Aksoy \& Ozyürük, 2015), investment priority decision model for logistics centers (Ozdemir et al., 2020). Including location selection of logistics villages, most of the previous studies performed by using multi-criteria decision-making techniques have considered different selection criteria such as technological infrastructure (Bottero et al., 2013), transport accessibility (Kayikci, 2010; Dablanc, 2007; Altuntaş \& Tuna, 2015), demographics, availability of the land, skilled labor availability (Tsamboulas \& Kapros, 2003; Nguyen \& Notteboom, 2017), existing multimodal transport options (Awasthi et al., 2011), quality of transportation infrastructure (Lipscomb et al., 2011; Vlachopoulou et al., 2001).

We recorded 45 studies dealing with location selection problems for logistics villages (centers) using MCDM approaches when we performed a comprehensive literature review. In these papers, different MCDM techniques were proposed, such as Analytic Hierarchy Process (AHP) (Tanyaş \& Bamyac1, 2008; Tomić et al., 2014), Analytic Network Process, (ANP) (Peker et al., 2016; Özceylan et al., 2016), Technique for Order Preference by Similarity to Ideal Solution (TOPSIS), (Wang \& Liu, 2007; Li et al., 2011; Can, 2012; Chen et al., 2014; Özceylan et al., 2016), Elimination et Choice Translating Reality (ELECTRE) (Goseiri \& Lessan, 2008; Can, 2012; Uysal \& Yavuz, 2014; Żak \& Weglinski, 2014; Fagaraşan \& Cristea, 2015; Cristea \& Cristea, 2016), VlseKriterijumska Optimizacija I Kompromisno Resenjetechnique (VIKOR) (Yıldırım \& Önder, 2014b), The Preference Ranking Organization Method for Enrichment of Evaluations (PROMETHEE) (Cristea \& Cristea, 2016; Yıldırım \& Önder, 2014a; Demiroğlu \& Elener, 2014), Artificial Neural Network (ANN) (Kayikci, 2010), DELPHI Method (Boile et al., 2010; Elgu \& Elitaş, 2011; Chen et al., 2014), Fuzzy Graph Theory (Uysal \& Gülmez, 2014). AHP and WASPAS (Mihajlović et al., 2019), DEMATEL and MAIRCA (Pamucar et al., 2018). Most of these papers trying to respond to the selection of location problems for logistics villages suggested objective evaluation techniques in the deterministic environment to solve site selection problems. However, some uncertainties are involved in decision-making problems related to logistics villages. Therefore, it is suitable to suggest a hybrid MCDM model in a fuzzy environment for obtaining more realistic and applicable results. On the other hand, there are some studies performed using fuzzy evaluation techniques.

However, the fuzzy TOPSIS (Uyanık, 2016; Erkayman et al., 2011) and Fuzzy AHP techniques (Chen \& Qu, 2006; Wang \& Liu, 2007; Goseiri \& Lessan, 2008; Kayikci, 2010; Önden et al., 2018) commonly used MCDM techniques. Besides, the fuzzy VIKOR, (Zalluhoğlu et al., 2014) and the fuzzy PROMETHEE, the fuzzy SWARA and CoCoSo, (Ulutaş et al., 2020), and Axiomatic Fuzzy Set (AFS) (Li et al., 2011), Single-Valued Neutrosophic (SVNN) 
Multi-Attributive Border Approximation Area Comparison (MABAC) (Pamucar \& Božanić, 2019) are the examples using different fuzzy MCDM methods in the literature.

Although these papers are valuable and have contributions to the existing literature, their contributions are limited due to structural problems and drawbacks of the MCDM frameworks proposed by these papers. First, the AHP technique is the most criticized method, as it requires many pairwise comparisons and computations. These problems make it difficult the implementation the technique and cause it to be more complicated. Furthermore, it suffers from the rank reversal problem. If we add or remove any criterion or alternative, the final ranking results may change dramatically. Hence, it is not sufficiently reliable for decisionmakers. Also, it requires to use of an additional technique for calculating the consistency. Similarly, the results obtained by using the TOPSIS technique are not reliable due to the rank reversal problem also.

In addition, the IMF SWARA and the fuzzy MABAC techniques were used in the literature for solving various decision-making problems. Vrtagić et al. (2021) applied the IMF SWARA approach to evaluate the road sections with respect to traffic management. Also, the fuzzy MABAC approach was implemented for solving decision-making problems encountered in various fields. The main focal points of these papers can be summarized as follows: evaluation of the efficiency of social media using (Sun et al., 2019; Bobar et al., 2020), Risk assessment of rockburst (Liang et al., 2019), Assessment of undergraduate teaching (Gong et al., 2019), strategy selection for health tourism (Büyüközkan et al., 2020), the selection of location for the construction of single-span bailey bridge (Božanić et al., 2019), green supplier selection (Zhang et al., 2021), Selection of fire position of mortar units (Jokić et al., 2021), Selection of commercially available electric vehicle (Biswas \& Das, 2019). As a result, studies focusing on logistics villages from the perspective of logistics companies and operators' preferences are limited. Most of them examined these villages in the location selection problem, and they suggested some evaluation tool at the macro scale for investment decisions of public and private sectors. In addition to that, the proposed models are mostly classical objective, subjective, and fuzzy assessment techniques. Moreover, the selection criteria used in these evaluations are mostly the same or similar. The numbers of different criteria that were added to the scope of analyses in previous studies are limited.

\section{The suggested model}

The suggested fuzzy integrated approach is implemented in four stages. In the first stage, the board of experts consisting of five professionals in the field of was constructed industry determines the selection criteria and decision options. Besides, these experts made linguistic evaluations about the relative importance of these criteria and options during this stage. In the second stage of the model, the improved fuzzy step-wise weight assessment ratio analysis (IMF SWARA) technique was applied to calculate the selection criteria' weights. The fuzzy Multi-Attributive Border Approximation Area Comparison (F-MABAC) method was implemented to determine the decision options' ranking performances of the decision stage of the fuzzy integrated MCDM model. In the final stage, a sensitivity analysis was performed to validate the proposed fuzzy MCDM model. The proposed integrated fuzzy MCDM model and its flowchart are given in Figure 1. 


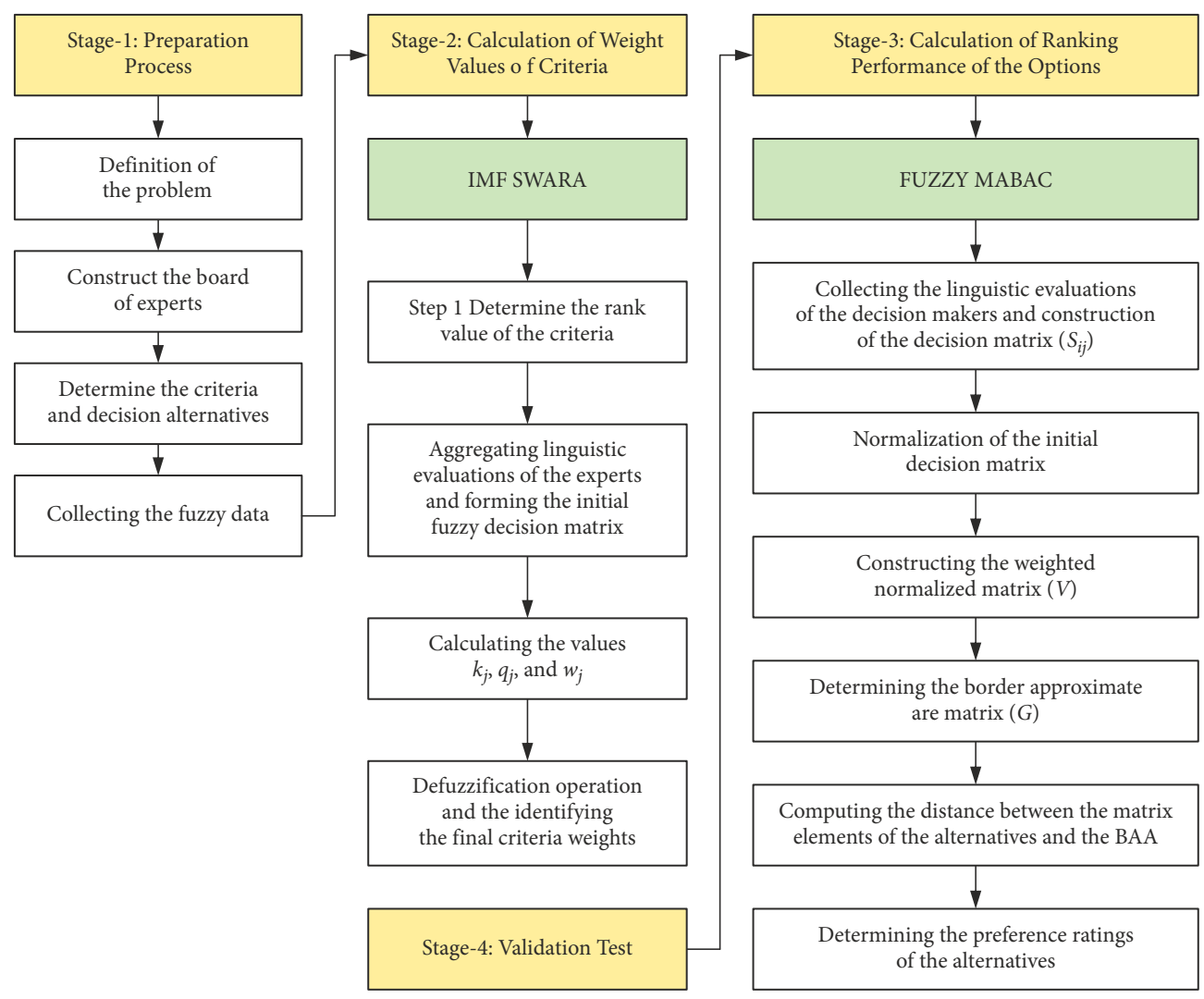

Figure 1. The flowchart of the proposed fuzzy hybrid model

\subsection{The preparation process}

In the first stage of the proposed model, many round-table meetings with the board members were organized, and the selection criteria and decision options used in the study were determined together with the board of experts. The board members were selected among high professionals, and some criteria have been considered for this selection. Being highly expert in the field of the logistics industry is determined as the first stipulate by researchers. Secondly, having advanced level professional experience (i.e., working in the industry for at least 15 years as a senior executive or company owner) and being a member of the board of a professional association is the third condition to be a member of the board of experts. Already, the selected members of the board of experts have a determinative role in logistics and transportation, as all of them are the executive board members of the professional association, having 1200 members consisting of logistics company owners. Hence, their opinions and evaluations are enough to make a reasonable and realistic assessment. In addition, including more members having fewer experiences and knowledge than these top senior executive members to the board may cause to include some excessive and undesirable evaluations, and it can affect the reliability of the evaluation process. According to these conditions, the list of the members of the board of experts are given below (Table 1). 
Table 1. The board of experts and their details

\begin{tabular}{|c|l|c|l|c|l|}
\hline D.M. & \multicolumn{1}{|c|}{ Duty } & Year & \multicolumn{1}{c|}{ Graduate } & Degree & \multicolumn{1}{c|}{ Association } \\
\hline DM-1 & Senior Executive & 27 & Business Man. & M.A & Vice-President \\
\hline DM-2 & Company Owner & 33 & Economy & B. A & Exe. comm. member \\
\hline DM-3 & Company Owner & 24 & Construction Eng. & M.A & Member of board \\
\hline DM-4 & Senior Executive & 18 & Industrial Eng. & B. A & Exe. comm. member \\
\hline DM-5 & Senior Executive & 24 & Naval Eng. & M.A & Exe. comm. member \\
\hline
\end{tabular}

At first, open-ended questions were directed to them and requested to prepare a list of the selection criteria and options essential in an assessment process about logistics village selection. After these lists were collected, repetitive criteria and options were eliminated, and the final selection criteria and alternatives were obtained. These criteria and definitions are presented in Table 2 .

Table 2. The decision alternatives and the selection criteria

\begin{tabular}{|c|c|c|c|c|}
\hline Criteria & Code & Definitions & Decision Options & Code \\
\hline $\begin{array}{l}\text { GNP of the City } \\
(000 \mathrm{TL})\end{array}$ & $\mathrm{C} 1$ & $\begin{array}{l}\text { It refers to Gross National } \\
\text { Product of each option }\end{array}$ & Samsun (Gelemen) & A1 \\
\hline $\begin{array}{l}\text { Number of } \\
\text { Enterprises }\end{array}$ & $\mathrm{C} 2$ & $\begin{array}{l}\text { The number of firms available } \\
\text { in each city }\end{array}$ & İzmit (Köseköy) & A2 \\
\hline Population & $\mathrm{C} 3$ & $\begin{array}{l}\text { The number of habitants living } \\
\text { in each city }\end{array}$ & Uşak & A3 \\
\hline $\begin{array}{l}\text { Distance to the } \\
\text { nearest port }\end{array}$ & $\mathrm{C} 4$ & $\begin{array}{l}\text { Distance to the nearest port } \\
\text { in terms of } \mathrm{km}\end{array}$ & İstanbul (Halkali) & A4 \\
\hline Total square meter & C5 & $\begin{array}{l}\text { Total square meter for each } \\
\text { option }\end{array}$ & Balikesir (Gökköy) & A5 \\
\hline Number of employees & $\mathrm{C} 6$ & $\begin{array}{l}\text { The number of employees } \\
\text { available in options }\end{array}$ & Eskişehir (Hasanbey) & A6 \\
\hline $\begin{array}{l}\text { Number of ports } \\
\text { within } 300 \mathrm{~km}\end{array}$ & $\mathrm{C} 7$ & The number of reachable ports & Denizli (Kaklik) & A7 \\
\hline $\begin{array}{l}\text { Distance to the } \\
\text { nearest airport }\end{array}$ & $\mathrm{C} 8$ & $\begin{array}{l}\text { Distance to the nearest airport } \\
\text { in terms of } \mathrm{km}\end{array}$ & $\begin{array}{l}\text { Kahramanmaraş } \\
\text { (Türkoğlu) }\end{array}$ & A8 \\
\hline $\begin{array}{l}\text { The industrial zone } \\
\text { in } 300 \mathrm{~km}\end{array}$ & C9 & $\begin{array}{l}\text { The number of industrial zones } \\
\text { near to options }\end{array}$ & & \\
\hline
\end{tabular}

\subsection{Improved Fuzzy Step-Wise Weight Assessment Ratio Analysis (IMF SWARA) Technique}

The SWARA technique introduced by Kersuliene et al. (2010) is an MCDM technique used to calculate the weights of the selection criteria (Kersuliene et al., 2010). Unlike the classical MCDM method, According to Mardani et al. (2017), the SWARA method tries to estimate decision-makers' preferences and includes these estimations to evaluate the process (Mardani et al., 2017). The SWARA technique has an algorithm that can be followed easily by decisionmakers, and the weights of the criteria can be determined by following these implementation 
steps. In addition, the fuzzy SWARA technique (F SWARA) (Mavi et al., 2017) developed based on the fuzzy sets to overcome many ambiguities existing in an evaluation process is a subjective evaluation technique. It has been used as a mathematical tool for making more rational and reasonable decisions (Percin, 2018; Zarbakhshnia et al., 2018; Sengul \& Cagil, 2020). However, Vrtagić et al. (2021) highlighted that the linguistic scale used for making the pairwise comparison between criteria (Mavi et al., 2017) is not sufficient, and they proposed to use a new scale by improving to fill the deficiency of the technique (Vrtagić et al., 2021). They introduced the improved fuzzy step-wise weight assessment ratio analysis (IMF SWARA), a novel approach within this scope. According to the authors, if decision-makers perform a linguistic evaluation as equally significant the jth criterion with respect to the jth-1 criterion, TFN is identified as $(1,1,1)$ according to the main assumptions of the F SWARA technique, and it is not possible to obtain equal weights for these criteria as a result of computations. However, if we use the linguistic scale proposed by the IMF SWARA technique, the TFN can be identified as $(0,0,0)$; thus, it is possible to obtain the final weights of these criteria are equal to each other (Vrtagić et al., 2021). When impacts of the criteria weights on the ranking of the decision alternatives are evaluated (Ecer, 2020), it is crucial to present a consistent and realistic evaluation tool to reflect the subjective evaluations performed by DMs (Vrtagić et al., 2021). For this purpose, we decided to use the IMF SWARA technique to identify the criteria weights and the technique's implementation steps as follows (Vrtagić et al., 2021).

Step 1. Determine the rank value of the criteria: In the first implementation step of the IMF SWARA technique decision-makers, decide the ranking value of the criteria, and they rank these criteria considering their evaluations. While the essential factor is ranked first, the minor significant factor is ranked last.

Step 2. Making pairwise comparisons between criteria: Decision-makers (DMs) determine the relative significance of each criterion with the help of the linguistic scale given in Table 3 . For this purpose, DMs identify the proportional significance of the jth criterion with respect to jth-1. Each criterion is compared previous one, and these relationships (ratio) are symbolized as $\bar{s}_{j}$ and it is expressed as the comparative significance of average value (Kersuliene et al., 2010; Vrtagić et al., 2021).

Table 3. The linguistic scale for the IMF SWARA technique and TFNs (Vrtagić et al., 2021)

\begin{tabular}{|l|c|c|c|c|}
\hline \multicolumn{1}{|c|}{ Linguistic Variable } & Abbreviation & \multicolumn{3}{c|}{ TFN Scale } \\
\hline Absolutely less significant & ALS & 1.000 & 1.000 & 1.000 \\
\hline Dominantly less significant & DLS & $1 / 2$ & $2 / 3$ & 1.000 \\
\hline Much less significant & MLS & $2 / 5$ & $1 / 2$ & $2 / 3$ \\
\hline Really less significant & RLS & $1 / 3$ & $2 / 5$ & $1 / 2$ \\
\hline Less significant & LS & $2 / 7$ & $1 / 3$ & $2 / 5$ \\
\hline Moderately less significant & MDLS & $1 / 4$ & $2 / 7$ & $1 / 3$ \\
\hline Weakly less significant & WLS & $2 / 9$ & $1 / 4$ & $2 / 7$ \\
\hline Equally significant & ES & 0.000 & 0.000 & 0.000 \\
\hline
\end{tabular}


Step 3. Computing the coefficient value: In this implementation step, recalculated weight values of the factors are determined, and final relative importance scores of the selection criteria are computed. The coefficient value is calculated as follows (Percin, 2018; Kersuliene et al., 2010):

$$
\tilde{k}_{j}=\left\{\begin{array}{rr}
\tilde{1}, & j=1 \\
\tilde{s}_{j}+1, & j>1
\end{array} .\right.
$$

Afterward, weights values of the criteria $\left(\tilde{q}_{j}\right)$ are calculated by using Equation (2):

$$
\tilde{q}_{j}=\left\{\begin{array}{c}
\tilde{1}, j=1 \\
\frac{\tilde{q}_{j-1}}{k_{j}}, j>1
\end{array} .\right.
$$

Finally, fuzzy weight coefficients values of the criteria are calculated with the help of Equation (3):

$$
\tilde{w}_{j}=\frac{\tilde{q}_{j}}{\sum_{j=1}^{n} \tilde{q}_{j}},
$$

where $\tilde{k}_{j}$ is coefficient values of criterion, $\tilde{q}_{j}$ is the recalculated fuzzy weight of the $j^{\text {th }}$ criterion $\tilde{w}_{j}$ denotes fuzzy relative weight values of $j^{\text {th }}$ criterion, $\mathrm{n}$ is the total number of criteria.

Step 4. Defuzzying the criteria weights: In the final step of the IMF SWARA technique, fuzzy values are defuzzied by using Equation (4) as follows (Stankovic et al., 2020):

$$
w_{\text {Crisp Value }}=\frac{w^{(l)}+4 w^{(m)}+w^{(u)}}{6} .
$$

\subsection{The Fuzzy Multi-Attributive Border Approximation Area Comparison (MABAC) Technique (FMABAC)}

The Multi-Attributive Border Approximation Area Comparison (MABAC) method is one of the novels MCDM techniques developed by Pamucar and Cirovic (2015). The MABAC technique provides an opportunity to tolerate undesirable and excessive values existing in the indexes, and it considers the distance of each alternative to the border approximation area (Ecer, 2020). This technique has an easily applicable algorithm, and it provides quite consistent and reasonable results. Furthermore, it gives importance to potential earnings and loss (Ecer, 2020; Puška et al., 2021). The implementation steps of the technique used for identifying the preference ratings of the alternatives are presented as follows (Pamucar \& Cirovic, 2015; Bobar et al., 2020; Nedeljković et al., 2021; Jokić et al., 2021; Božanić et al., 2019).

Step 1. Generating the initial decision matrix $(\tilde{S})$ : In the first implementation step of the fuzzy MABAC method, the initial decision matrix is constructed by evaluating m number of options by n number of selection criteria. Let suppose the form of the vector for alternatives with respect to the selection criteria is expressed as $A_{i}=\left(\tilde{s}_{i 1}, \tilde{s}_{i 2}, \ldots, \tilde{s}_{i n}\right)$ where $\tilde{s}_{i j}$ is the value of the $i$-th alternative according to the $j$-th criterion $(i=1,2, \ldots, m ; j=1,2, \ldots, n)$. The 
initial decision matrix is given as follows (Puška et al., 2021):

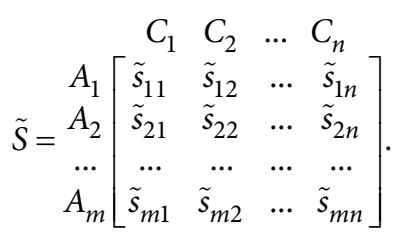

Step 2. Normalization of the initial decision matrix $\left(\tilde{N}^{*}\right)$ : Using Equations (6) and (7), the elements of the decision matrix are normalized.

$$
\begin{aligned}
& \tilde{\eta}_{i j}=\left(\frac{s_{i j}-s_{i}^{-}}{s_{i}^{+}-s_{i}^{-}}\right) \text {benefit-type criteria; } \\
& \tilde{\eta}_{i j}=\left(\frac{s_{i j}-s_{i}^{+}}{s_{i}^{-}-s_{i}^{+}}\right) \text {cost }- \text { type criteria, }
\end{aligned}
$$

where for benefit criteria, Equation (6), for cost criteria Equation (7) is applied. While $s_{i j}{ }^{+}$ symbolizes maximum values of right distributions of the observed criterion by alternatives, $s_{i j}{ }^{-}$is the minimum value of the left distribution of fuzzy numbers of the observed criterion by alternatives (Demiroğlu \& Elener, 2014). The normalized matrix is given as the following equation:

$$
\tilde{N}^{*}=\begin{gathered}
A_{1} \\
A_{2} \\
\ldots \\
A_{m}
\end{gathered}\left[\begin{array}{cccc}
\tilde{\eta}_{11} & C_{2} & \ldots & \tilde{\eta}_{12} \\
\tilde{\eta}_{21} & \tilde{\eta}_{22} & \ldots & \tilde{\eta}_{2 n} \\
\ldots & \ldots & \ldots & \ldots \\
\tilde{\eta}_{m 1} & \tilde{\eta}_{m 2} & \ldots & \tilde{\eta}_{m n}
\end{array}\right] .
$$

Step 3. Construction of the weighted matrix $(\tilde{V})$ : Values of the weighted matrix elements are computed with the help of Equation (9):

$$
\tilde{\vartheta}_{i j}=w_{i} \bullet \tilde{\eta}_{i j}+w_{i} .
$$

Equation (9) $w_{i}$ represents the weight coefficients of the criteria while $\tilde{\eta}_{i j}$ is the element values of the normalized matrix. As a result, the weighted matrix $(\tilde{V})$ is presented as Equation (10):

$$
\tilde{V}=\left[\begin{array}{cccc}
\tilde{\vartheta}_{11} & \tilde{\vartheta}_{12} & \ldots & \tilde{\vartheta}_{1 n} \\
\tilde{\vartheta}_{21} & \tilde{\vartheta}_{22} & \ldots & \tilde{\vartheta}_{2 n} \\
\ldots & \ldots & \ldots & \ldots \\
\tilde{\vartheta}_{m 1} & \tilde{\vartheta}_{m 2} & \ldots & \tilde{\vartheta}_{m n}
\end{array}\right] .
$$

Step 4. Determining the approximate border area matrix $(\tilde{G})$ : In this step, the approximate border area (BBA) for every criterion is computed with the help of Equation (11):

$$
\tilde{g}_{i}=\left(\prod_{j=1}^{m} \tilde{\vartheta}_{i j}\right)^{1 / m}
$$

where $\tilde{\vartheta}_{i j}$ represents the elements of the weighted matrix. After these values are computed, the border approximate areas matrix, which has the form of $n x l$, is generated as follows:

$$
\left.\tilde{G}=\begin{array}{cccc}
C_{1} & C_{2} & \ldots & C_{n} \\
\tilde{g}_{1} & \tilde{g}_{2} & \ldots & \tilde{g}_{n}
\end{array}\right] .
$$


Step 5. Computing the distance between the matrix elements of alternatives and the approximate border area $(\tilde{G})$ in the $5^{\text {th }}$ step of the technique, distances between the matrix elements of alternatives and the approximate border area $\left(\tilde{q}_{i j}\right)$, are calculated, and the $\tilde{Q}$ matrix showing these computed values is constructed.

$$
\begin{aligned}
\tilde{Q} & =\tilde{V}-\tilde{G} \\
\tilde{Q} & =\left[\begin{array}{cccc}
\tilde{q}_{11} & \tilde{q}_{12} & \ldots & \tilde{q}_{1 n} \\
\tilde{q}_{21} & \tilde{q}_{22} & \ldots & \tilde{q}_{2 n} \\
\ldots & \ldots & \ldots & \ldots \\
\tilde{q}_{m 1} & \tilde{q}_{m 2} & \ldots & \tilde{q}_{m n}
\end{array}\right] .
\end{aligned}
$$

The values of alternative $\widetilde{A}_{i}$ may belong to the approximate border area $(\widetilde{G})$, to the upper approximate area $\left(\widetilde{G}^{+}\right)$, or the lower approximate area $\left(\widetilde{G}^{-}\right)$, i.e., $\widetilde{A}_{i} \in\left\{\widetilde{G} \vee \widetilde{G}^{+} \vee \widetilde{G}^{-}\right\}$.

The belonging of alternative $A_{i}$ to the approximation area $\left(\tilde{G}, \tilde{G}^{+}\right.$or $\left.\tilde{G}^{-}\right)$is determined based on Equation (15).

$$
\widetilde{A}_{i} \in \begin{cases}\widetilde{G}^{+} & \text {if } \tilde{q}_{i j}>0 \\ \widetilde{G} & \text { if } \tilde{q}_{i j}=0 . \\ \widetilde{G}^{-} & \text {if } \tilde{q}_{i j}<0\end{cases}
$$

Step 6. Determining the options' ranking performances: The sum of the alternatives' distance from the approximate border areas shows the options' relative importance scores. The alternatives' final ranking scores are obtained by summing up the elements of the matrix $\tilde{Q}$ (Equation (14)) per row with the help of expression (16).

$$
\tilde{\Psi}_{i}=\sum_{j=1}^{n} \tilde{q}_{i j}, j=1,2,3, \ldots, n ; i=1,2,3, \ldots, m .
$$

Step 7. Determining the alternatives' final ranking performances: in the final implementation step, the values calculated in the previous step are defuzzified by applying the options defuzzification operations ranking performance scores. This operation is performed by using Equations (17) and (18). Afterward, decision alternatives are ranked considering their relative performance scores (Demiroğlu \& Elener, 2014):
a) defuzzy $\psi=\left[\left(q^{(u)}-q^{(l)}\right)+\left(q^{(m)}-q^{(l)}\right)\right] 3^{-1}+q^{(l)}$;
b) defuzzy $\psi=\left[\lambda q^{(u)}+q^{(m)}+(1-\lambda) q^{(l)}\right] 2^{-1}$.

\section{Applying the suggested fuzzy hybrid MCDM model}

The proposed fuzzy integrated MCDM model has been implemented to solve the selection of logistics villages that is the crucial issue for logistics operators and companies. While the weight values of the selection criteria have been calculated with the help of the IMF SWARA technique, the F MABAC technique has been implemented to evaluate the ranking performances of the decision alternatives. 


\subsection{Problem description}

When the main problem that motivated the current paper is considered, the main research question is the most suitable Logistics Village among the alternatives given in Figure 2 for logistics service providers and other stakeholders. Secondly, is there any mathematical model or methodological frame applied to solve these kinds of decision-making problems encountered in the field of logistics? or decision-makers, who are responsible for deciding for selecting a proper logistics center, decide based on their judgments and experiences when they encounter to these kinds of problems? Finally, researchers sought a reasonable answer to the significant criteria and factors affecting selecting appropriate logistics centers. For this purpose, researchers organized face-to-face interviews with each member of the board of experts and the well-attended round table meetings and directed these questions to the experts. At the end of the first round of the meetings, preparing a list for determining the selection criteria was requested from experts by researchers.

The first round of the preparation process shows no mathematical model implemented to solve these decision-making problems. According to the experts' opinions, decision-makers in logistics make decisions based on their own experiences. After the lists prepared by experts were collected, researchers eliminated the repetitive criteria. The final criteria were determined by providing complete consensus among the board members, as seen in Table 2 .

As a result, selecting appropriate logistics centers is a crucial task for decision-makers, and these kinds of decisions are strategic. They can affect the productivity, efficiency, and performance of logistics companies. In addition, It is a crucial factor in logistics costs for almost all logistics parties. Moreover, the logistics industry needs a mathematical model with an applicable algorithm to obtain more reasonable and realistic results to determine the best logistics village alternatives. The current paper suggests a methodological frame to meet these requirements of the field of the logistics industry.

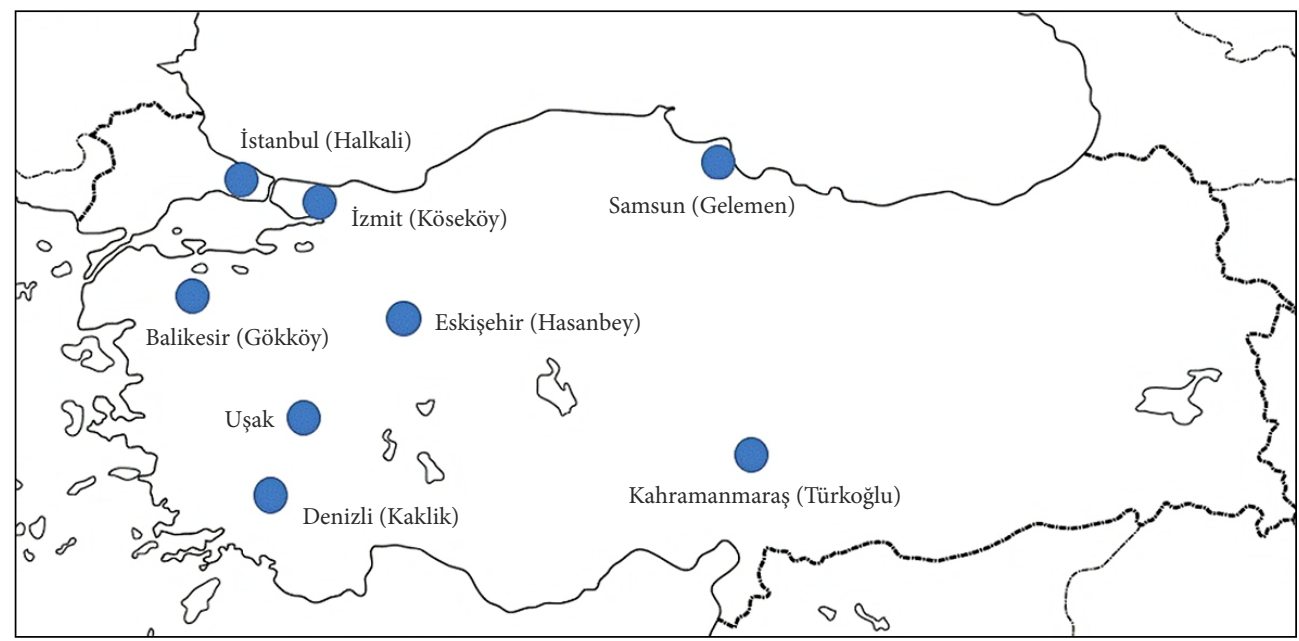

Figure 2. The decision alternatives for logistics village (centers) in Turkey 


\subsection{Determining the weights of the selection criteria}

In this phase of the research process, nine selection criteria affecting the selection process were determined considering the board of experts' opinions on this issue. In this phase of the research process, nine selection criteria affecting the selection process were determined considering the board of experts' opinions on this issue. For this purpose, researchers requested each decision-maker to prepare a list for the selection criteria. Next, researchers eliminated the repetitive criteria and identified a list of criteria in Table 4. Afterward, we requested decision-makers to give scores to each criterion between 1 and 9. Finally, we identified the relative importance score of each criterion by applying geometric mean operation, and we eliminated some criteria taking scores under 5 by providing complete consensus of decision-makers. As a result of the process, the final selection criteria using in the current paper were determined. The identified criteria by DMs and their relative significance scores are presented in Table 4.

Then, it was passed to the implementation phase of the IMF SWARA to determine the relative importance values of the criteria, and ranking of the criteria has been requested from five decision-makers from the most important criterion to the less critical criterion. Next, each decision-maker evaluates the criteria by considering the linguistic terms shown in Table 3 , and these evaluations convert the TFNs corresponding to the scale. The criteria weights are separately computed depending on these evaluations performed by each decision-maker with the help of Equations (1), (2), (3), and (4), respectively. The obtained criteria weights with respect to evaluations of the five experts are presented in Table 5.

Table 4. The selection criteria for second-hand Ro-Ro Vessels and relative importance scores

\begin{tabular}{|l|l|c|c|c|c|c|c|}
\hline Code & \multicolumn{1}{|c|}{ Criteria } & DM1 & DM2 & DM3 & DM4 & DM5 & Mean \\
\hline C1 & GNP of the City (000 TL) & 9 & 8 & 9 & 7 & 9 & 8.3596 \\
\hline C2 & Number of Enterprises & 8 & 7 & 8 & 6 & 8 & 7.3537 \\
\hline C3 & Population & 7 & 8 & 8 & 7 & 6 & 7.1599 \\
\hline C4 & Distance to nearest port & 7 & 7 & 8 & 6 & 7 & 6.9712 \\
\hline C5 & Total square meter & 7 & 7 & 6 & 7 & 7 & 6.7875 \\
\hline C6 & Number of employees & 6 & 6 & 7 & 7 & 8 & 6.7595 \\
\hline C7 & Number of ports within 300 km & 6 & 8 & 7 & 8 & 5 & 6.6939 \\
\hline C8 & Distance to nearest airport & 5 & 4 & 7 & 6 & 5 & 5.3046 \\
\hline C9 & Industrial zone within 300 km & 4 & 5 & 5 & 5 & 6 & 5.2331 \\
\hline C10 & Weather & 5 & 4 & 5 & 3 & 5 & 4.3174 \\
\hline C11 & Geology & 4 & 4 & 6 & 4 & 7 & 4.8516 \\
\hline C12 & Hydrology & 4 & 7 & 3 & 3 & 7 & 4.4596 \\
\hline C13 & Natural resource & 2 & 7 & 5 & 6 & 6 & 4.7894 \\
\hline C14 & Terrain conditions & 3 & 4 & 7 & 3 & 8 & 4.5803 \\
\hline C15 & Accident & 3 & 4 & 5 & 6 & 6 & 4.6440 \\
\hline C16 & Emissions & 5 & 4 & 3 & 3 & 2 & 3.2453 \\
\hline C17 & Height & 4 & 3 & 6 & 3 & 3 & 3.6502 \\
\hline C18 & Border crossing & 3 & 2 & 2 & 4 & 3 & 2.7019 \\
\hline C19 & Political stability & 2 & 1 & 2 & 3 & 1.8882 \\
\hline C20 & Interoperability & & & & \\
\hline
\end{tabular}


Table 5. The weights of criteria were calculated by using the IMF SWARA technique

\begin{tabular}{|c|c|c|c|c|c|c|c|c|c|c|c|c|c|}
\hline \multirow{3}{*}{$\begin{array}{c}\text { Criteria } \\
\mathrm{C} 1\end{array}$} & \multicolumn{13}{|c|}{ DM-1 } \\
\hline & \multicolumn{3}{|c|}{$\tilde{s}_{j}$} & \multicolumn{3}{|c|}{$\tilde{k}_{j}$} & \multicolumn{3}{|c|}{$\tilde{q}_{j}$} & \multicolumn{3}{|c|}{$\tilde{w}_{j}$} & $\begin{array}{l}\text { Crips } \\
\text { Value }\end{array}$ \\
\hline & - & - & - & 1.000 & 1.000 & 1.000 & 1.000 & 1.000 & 1.000 & 0.279 & 0.300 & 0.328 & 0.301 \\
\hline $\mathrm{C} 2$ & $1 / 3$ & $2 / 5$ & $1 / 2$ & 1.333 & 1.400 & 1.500 & 0.667 & 0.714 & 0.750 & 0.186 & 0.214 & 0.246 & 0.215 \\
\hline C3 & $2 / 7$ & $1 / 3$ & $2 / 5$ & 1.286 & 1.333 & 1.400 & 0.476 & 0.536 & 0.583 & 0.133 & 0.160 & 0.192 & 0.161 \\
\hline $\mathrm{C} 4$ & 1 & 1 & 1 & 2.000 & 2.000 & 2.000 & 0.238 & 0.268 & 0.292 & 0.067 & 0.080 & 0.096 & 0.081 \\
\hline C5 & $1 / 3$ & $2 / 5$ & $1 / 2$ & 1.333 & 1.400 & 1.500 & 0.159 & 0.191 & 0.219 & 0.044 & 0.057 & 0.072 & 0.058 \\
\hline C6 & 0 & 0 & 0 & 1.000 & 1.000 & 1.000 & 0.159 & 0.191 & 0.219 & 0.044 & 0.057 & 0.072 & 0.058 \\
\hline C7 & 0 & 0 & 0 & 1.000 & 1.000 & 1.000 & 0.159 & 0.191 & 0.219 & 0.044 & 0.057 & 0.072 & 0.058 \\
\hline $\mathrm{C} 8$ & $2 / 7$ & $1 / 3$ & $2 / 5$ & 1.286 & 1.333 & 1.400 & 0.113 & 0.143 & 0.170 & 0.032 & 0.043 & 0.056 & 0.043 \\
\hline C9 & $1 / 3$ & $2 / 5$ & $1 / 2$ & 1.333 & 1.400 & 1.500 & 0.076 & 0.102 & 0.128 & 0.021 & 0.031 & 0.042 & 0.031 \\
\hline \multirow[b]{2}{*}{ Criteria } & \multicolumn{13}{|c|}{ DM-2 } \\
\hline & \multicolumn{3}{|c|}{$\tilde{s}_{j}$} & \multicolumn{3}{|c|}{$\tilde{k}_{j}$} & \multicolumn{3}{|c|}{$\tilde{q}_{j}$} & \multicolumn{3}{|c|}{$\tilde{w}_{j}$} & $\begin{array}{l}\text { Crips } \\
\text { Value }\end{array}$ \\
\hline C2 & - & - & - & 1.000 & 1.000 & 1.000 & 1.000 & 1.000 & 1.000 & 0.279 & 0.300 & 0.328 & 0.301 \\
\hline $\mathrm{C} 1$ & $1 / 3$ & $2 / 5$ & $1 / 2$ & 1.333 & 1.400 & 1.500 & 0.667 & 0.714 & 0.750 & 0.186 & 0.214 & 0.246 & 0.215 \\
\hline C3 & $2 / 7$ & $1 / 3$ & $2 / 5$ & 1.286 & 1.333 & 1.400 & 0.476 & 0.536 & 0.583 & 0.133 & 0.160 & 0.192 & 0.161 \\
\hline $\mathrm{C} 4$ & 1 & 1 & 1 & 2.000 & 2.000 & 2.000 & 0.238 & 0.268 & 0.292 & 0.067 & 0.080 & 0.096 & 0.081 \\
\hline C5 & $1 / 3$ & $2 / 5$ & $1 / 2$ & 1.333 & 1.400 & 1.500 & 0.159 & 0.191 & 0.219 & 0.044 & 0.057 & 0.072 & 0.058 \\
\hline C6 & 0 & 0 & 0 & 1.000 & 1.000 & 1.000 & 0.159 & 0.191 & 0.219 & 0.044 & 0.057 & 0.072 & 0.058 \\
\hline C7 & 0 & 0 & 0 & 1.000 & 1.000 & 1.000 & 0.159 & 0.191 & 0.219 & 0.044 & 0.057 & 0.072 & 0.058 \\
\hline $\mathrm{C} 8$ & $2 / 7$ & $1 / 3$ & $2 / 5$ & 1.286 & 1.333 & 1.400 & 0.113 & 0.143 & 0.170 & 0.032 & 0.043 & 0.056 & 0.043 \\
\hline C9 & $1 / 3$ & $2 / 5$ & $1 / 2$ & 1.333 & 1.400 & 1.500 & 0.076 & 0.102 & 0.128 & 0.021 & 0.031 & 0.042 & 0.031 \\
\hline \multirow{2}{*}{ Criteria } & \multicolumn{13}{|c|}{ DM-3 } \\
\hline & \multicolumn{3}{|c|}{$\tilde{s}_{j}$} & \multicolumn{3}{|c|}{$\tilde{k}_{j}$} & \multicolumn{3}{|c|}{$\tilde{q}_{j}$} & \multicolumn{3}{|c|}{$\tilde{w}_{j}$} & $\begin{array}{l}\text { Crips } \\
\text { Value }\end{array}$ \\
\hline $\mathrm{C} 1$ & - & - & - & 1.000 & 1.000 & 1.000 & 1.000 & 1.000 & 1.000 & 0.282 & 0.317 & 0.366 & 0.319 \\
\hline $\mathrm{C} 2$ & $1 / 3$ & $2 / 5$ & $1 / 2$ & 1.333 & 1.400 & 1.500 & 0.667 & 0.714 & 0.750 & 0.188 & 0.226 & 0.275 & 0.228 \\
\hline C3 & $1 / 3$ & $2 / 5$ & $1 / 2$ & 1.333 & 1.400 & 1.500 & 0.444 & 0.510 & 0.563 & 0.126 & 0.162 & 0.206 & 0.163 \\
\hline $\mathrm{C} 4$ & $2 / 5$ & $1 / 2$ & $2 / 3$ & 1.400 & 1.500 & 1.667 & 0.267 & 0.340 & 0.402 & 0.075 & 0.108 & 0.147 & 0.109 \\
\hline C5 & $1 / 2$ & $2 / 3$ & 1 & 1.500 & 1.667 & 2.000 & 0.133 & 0.204 & 0.268 & 0.038 & 0.065 & 0.098 & 0.066 \\
\hline C6 & $1 / 3$ & $2 / 5$ & $1 / 2$ & 1.333 & 1.400 & 1.500 & 0.089 & 0.146 & 0.201 & 0.025 & 0.046 & 0.074 & 0.047 \\
\hline C7 & $2 / 7$ & $1 / 3$ & $2 / 5$ & 1.286 & 1.333 & 1.400 & 0.063 & 0.109 & 0.156 & 0.018 & 0.035 & 0.057 & 0.036 \\
\hline $\mathrm{C} 8$ & $1 / 3$ & $2 / 5$ & $1 / 2$ & 1.333 & 1.400 & 1.500 & 0.042 & 0.078 & 0.117 & 0.012 & 0.025 & 0.043 & 0.026 \\
\hline C9 & $2 / 5$ & $1 / 2$ & $2 / 3$ & 1.400 & 1.500 & 1.667 & 0.025 & 0.052 & 0.084 & 0.007 & 0.017 & 0.031 & 0.017 \\
\hline
\end{tabular}


End of Table 5

\begin{tabular}{|c|c|c|c|c|c|c|c|c|c|c|c|c|c|}
\hline \multirow{3}{*}{$\begin{array}{c}\text { Criteria } \\
\mathrm{C} 1\end{array}$} & \multicolumn{13}{|c|}{ DM-4 } \\
\hline & \multicolumn{3}{|c|}{$\tilde{s}_{j}$} & \multicolumn{3}{|c|}{$\tilde{k}_{j}$} & \multicolumn{3}{|c|}{$\tilde{q}_{j}$} & \multicolumn{3}{|c|}{$\tilde{w}_{j}$} & $\begin{array}{l}\text { Crips } \\
\text { Value }\end{array}$ \\
\hline & - & - & - & 1.000 & 1.000 & 1.000 & 1.000 & 1.000 & 1.000 & 0.222 & 0.243 & 0.274 & 0.245 \\
\hline $\mathrm{C} 2$ & $2 / 7$ & $1 / 3$ & $2 / 5$ & 1.286 & 1.333 & 1.400 & 0.714 & 0.750 & 0.778 & 0.159 & 0.183 & 0.213 & 0.184 \\
\hline $\mathrm{C} 3$ & 0 & 0 & 0 & 1.000 & 1.000 & 1.000 & 0.714 & 0.750 & 0.778 & 0.159 & 0.183 & 0.213 & 0.184 \\
\hline $\mathrm{C} 4$ & $1 / 3$ & $2 / 5$ & $1 / 2$ & 1.333 & 1.400 & 1.500 & 0.476 & 0.536 & 0.583 & 0.106 & 0.130 & 0.160 & 0.131 \\
\hline C5 & $1 / 2$ & $2 / 3$ & 1 & 1.500 & 1.667 & 2.000 & 0.238 & 0.321 & 0.389 & 0.053 & 0.078 & 0.107 & 0.079 \\
\hline C6 & $2 / 7$ & $1 / 3$ & $2 / 5$ & 1.286 & 1.333 & 1.400 & 0.170 & 0.241 & 0.302 & 0.038 & 0.059 & 0.083 & 0.059 \\
\hline C7 & 0 & 0 & 0 & 1.000 & 1.000 & 1.000 & 0.170 & 0.241 & 0.302 & 0.038 & 0.059 & 0.083 & 0.059 \\
\hline C8 & $2 / 5$ & $1 / 2$ & $2 / 3$ & 1.400 & 1.500 & 1.667 & 0.102 & 0.161 & 0.216 & 0.023 & 0.039 & 0.059 & 0.040 \\
\hline C9 & $2 / 5$ & $1 / 2$ & $2 / 3$ & 1.400 & 1.500 & 1.667 & 0.061 & 0.107 & 0.154 & 0.014 & 0.026 & 0.042 & 0.027 \\
\hline \multirow{2}{*}{ Criteria } & \multicolumn{13}{|c|}{ DM-5 } \\
\hline & \multicolumn{3}{|c|}{$\tilde{s}_{j}$} & \multicolumn{3}{|c|}{$\tilde{k}_{j}$} & \multicolumn{3}{|c|}{$\tilde{q}_{j}$} & \multicolumn{3}{|c|}{$\overline{w_{j}}$} & $\begin{array}{l}\text { Crips } \\
\text { Value }\end{array}$ \\
\hline $\mathrm{C} 1$ & - & - & - & 1.000 & 1.000 & 1.000 & 1.000 & 1.000 & 1.000 & 0.287 & 0.324 & 0.378 & 0.327 \\
\hline $\mathrm{C} 2$ & $1 / 3$ & $2 / 5$ & $1 / 2$ & 1.333 & 1.400 & 1.500 & 0.667 & 0.714 & 0.750 & 0.191 & 0.232 & 0.284 & 0.234 \\
\hline $\mathrm{C} 3$ & $1 / 3$ & $2 / 5$ & $1 / 2$ & 1.333 & 1.400 & 1.500 & 0.444 & 0.510 & 0.563 & 0.128 & 0.165 & 0.213 & 0.167 \\
\hline $\mathrm{C} 4$ & $1 / 2$ & $2 / 3$ & 1 & 1.500 & 1.667 & 2.000 & 0.222 & 0.306 & 0.375 & 0.064 & 0.099 & 0.142 & 0.100 \\
\hline C5 & $1 / 2$ & $2 / 3$ & 1 & 1.500 & 1.667 & 2.000 & 0.111 & 0.184 & 0.250 & 0.032 & 0.060 & 0.095 & 0.061 \\
\hline C6 & $2 / 7$ & $1 / 3$ & $2 / 5$ & 1.286 & 1.333 & 1.400 & 0.079 & 0.138 & 0.194 & 0.023 & 0.045 & 0.074 & 0.046 \\
\hline C7 & $2 / 7$ & $1 / 3$ & $2 / 5$ & 1.286 & 1.333 & 1.400 & 0.057 & 0.103 & 0.151 & 0.016 & 0.033 & 0.057 & 0.035 \\
\hline C8 & $2 / 7$ & $1 / 3$ & $2 / 5$ & 1.286 & 1.333 & 1.400 & 0.040 & 0.077 & 0.118 & 0.012 & 0.025 & 0.044 & 0.026 \\
\hline C9 & $2 / 5$ & $1 / 2$ & $2 / 3$ & 1.400 & 1.500 & 1.667 & 0.024 & 0.052 & 0.084 & 0.007 & 0.017 & 0.032 & 0.018 \\
\hline
\end{tabular}

Then, we calculated the geometric mean of criteria weights, and the final weights of the criteria were obtained, as shown in Table 6.

Table 6. The final criteria weights

\begin{tabular}{|l|c|c|}
\hline \multicolumn{1}{|c|}{ Criteria } & Code & Final weights \\
\hline GNP of the City (000 TL) & C1 & 0.278 \\
\hline Number of Enterprises & C2 & 0.229 \\
\hline Population & C3 & 0.167 \\
\hline Distance to the nearest port & C4 & 0.099 \\
\hline Total squaremeter & C5 & 0.064 \\
\hline Number of employees & C6 & 0.053 \\
\hline Number of the port within $300 \mathrm{~km}$ & C7 & 0.048 \\
\hline Distance to the nearest airport & C8 & 0.035 \\
\hline The industrial zone within $300 \mathrm{~km}$ & C9 & 0.024 \\
\hline
\end{tabular}


Following Table 6, the city's C1 GNP is the most crucial criterion for decision-makers with a relative importance score of 0.278 . Also, it has been observed that while $\mathrm{C} 2$ the number of the business is the second important factor with the score of 0.229 , C9 the number of organized industrial zones around $300 \mathrm{~km}$ is the less critical criterion with the relative importance score of 0.024 .

\subsection{Evaluation of the alternatives on logistics village selection}

After the weights of the criteria have been determined using the IMF SWARA technique, the F MABAC technique has been applied to solve the decision-making problems related to selecting the most appropriate logistics village. Making linguistic evaluations for decision options based on each criterion was requested from the five experts who are members of the board of experts by using the linguistic evaluation scale given in Table 7 (Stankovic et al., 2020).

Table 7. Linguistic comparison scales for decision options (Stankovic et al., 2020)

\begin{tabular}{|l|c|c|c|c|}
\hline \multicolumn{1}{|c|}{ Linguistic Variable } & Abbreviation & \multicolumn{3}{c|}{ TFN Scale } \\
\hline Extremely Poor & EP & 1 & 1 & 1 \\
\hline Very Poor & VP & 1 & 1 & 3 \\
\hline Poor & P & 1 & 3 & 3 \\
\hline Medium Poor & MP & 3 & 3 & 5 \\
\hline Medium & M & 3 & 5 & 5 \\
\hline Medium Good & MG & 5 & 5 & 7 \\
\hline Good & G & 5 & 7 & 7 \\
\hline Very Good & VG & 7 & 7 & 9 \\
\hline Extremely Good & EG & 7 & 9 & 9 \\
\hline
\end{tabular}

After the linguistic evaluations given in Appendix were converted to the TFNs corresponding in the linguistic evaluation scale presented in Table 6, the initial fuzzy decision matrix was constructed by applying geometric mean operation as shown in Table 8 .

Considering each selection criterion being the cost or benefit factor, the fuzzy decision matrix has been normalized with the cost or benefit factor's help. The fuzzy decision matrix has been normalized with Equations (6) and (7), and the normalized fuzzy matrix is shown in Table 9. While C4 and C8 are the cost factors in normalization operations, all other criteria are the benefit factors.

Then, using the weight values of criteria calculated with the help of the IMF SWARA technique in the first stage of the hybrid model, the fuzzy weighted normalized matrix has been constructed using Equation (9). The weighted normalized matrix is given in Table 10.

Afterward, with the help of Equation (11), which shows matrix elements in the Border Approximate Area (BAA) in the dimension of $1 \times 9$, have been computed and shown in Table 11. 
Table 8. The initial (aggregated) fuzzy decision matrix

\begin{tabular}{|c|c|c|c|c|c|c|c|c|c|}
\hline \multirow[b]{3}{*}{ Alternative } & \multicolumn{9}{|c|}{ Criteria } \\
\hline & \multicolumn{3}{|c|}{$\mathrm{C}_{1}(\mathrm{Max})$} & \multicolumn{3}{|c|}{$\mathrm{C}_{2}(\mathrm{Max})$} & \multicolumn{3}{|c|}{$\mathrm{C}_{3}(\mathrm{Max})$} \\
\hline & 1 & $\mathrm{~m}$ & $\mathrm{u}$ & 1 & $\mathrm{~m}$ & $\mathrm{u}$ & 1 & $\mathrm{~m}$ & $\mathrm{u}$ \\
\hline A1 & 1.552 & 2.141 & 3.680 & 1.552 & 1.719 & 2.954 & 5.720 & 7.237 & 7.740 \\
\hline A2 & 1.246 & 2.408 & 3.323 & 1.552 & 2.141 & 2.954 & 5.165 & 6.015 & 7.237 \\
\hline A3 & 1.933 & 2.371 & 3.272 & 1.246 & 1.933 & 2.667 & 1.552 & 1.719 & 2.954 \\
\hline A4 & 1.552 & 1.719 & 2.954 & 3.936 & 5.165 & 6.015 & 2.954 & 3.936 & 5.165 \\
\hline A5 & 3.936 & 5.165 & 6.015 & 2.954 & 3.936 & 5.165 & 5.165 & 6.544 & 7.237 \\
\hline A6 & 1.719 & 2.954 & 3.936 & 6.119 & 6.882 & 8.139 & 1.719 & 2.954 & 3.936 \\
\hline A7 & 2.036 & 3.160 & 4.427 & 5.165 & 6.015 & 7.237 & 2.371 & 3.500 & 4.663 \\
\hline \multirow[t]{2}{*}{$\mathrm{A} 8$} & 2.537 & 3.500 & 4.904 & 6.119 & 7.000 & 8.139 & 6.119 & 6.882 & 8.139 \\
\hline & \multicolumn{3}{|c|}{$\mathrm{C}_{4}(\mathrm{Min})$} & \multicolumn{3}{|c|}{$\mathrm{C}_{5}(\mathrm{Max})$} & \multicolumn{3}{|c|}{$\mathrm{C}_{6}(\mathrm{Max})$} \\
\hline Alternative & 1 & $\mathrm{~m}$ & $\mathrm{u}$ & 1 & $\mathrm{~m}$ & $\mathrm{u}$ & 1 & $\mathrm{~m}$ & $\mathrm{u}$ \\
\hline $\mathrm{A} 1$ & 1.000 & 1.552 & 3.000 & 2.954 & 3.743 & 4.146 & 1.552 & 1.719 & 2.954 \\
\hline $\mathrm{A} 2$ & 1.246 & 1.246 & 2.667 & 1.552 & 1.904 & 2.954 & 1.933 & 2.141 & 3.272 \\
\hline A3 & 1.552 & 2.141 & 2.954 & 1.933 & 2.371 & 3.272 & 1.246 & 1.380 & 2.667 \\
\hline A4 & 1.552 & 1.719 & 2.954 & 1.552 & 1.719 & 2.954 & 1.552 & 1.904 & 2.954 \\
\hline A5 & 2.954 & 3.936 & 5.165 & 2.371 & 2.627 & 3.743 & 2.954 & 3.936 & 5.165 \\
\hline A6 & 1.552 & 1.719 & 2.954 & 2.141 & 2.371 & 3.500 & 1.552 & 2.141 & 2.954 \\
\hline A7 & 2.954 & 3.936 & 5.165 & 3.272 & 4.663 & 5.524 & 1.719 & 2.954 & 3.936 \\
\hline \multirow[t]{2}{*}{ A8 } & 2.954 & 3.936 & 5.165 & 3.936 & 5.165 & 6.015 & 3.936 & 5.165 & 6.015 \\
\hline & \multicolumn{3}{|c|}{$\mathrm{C}_{7}(\operatorname{Max})$} & \multicolumn{3}{|c|}{$\mathrm{C}_{8}(\mathrm{Min})$} & \multicolumn{3}{|c|}{$\mathrm{C}_{9}$ (Max) } \\
\hline Alternative & 1 & $\mathrm{~m}$ & $\mathrm{u}$ & 1 & $\mathrm{~m}$ & $\mathrm{u}$ & 1 & $\mathrm{~m}$ & $\mathrm{u}$ \\
\hline $\mathrm{A} 1$ & 1.552 & 1.904 & 2.954 & 1.552 & 2.141 & 3.680 & 1.246 & 1.933 & 3.323 \\
\hline A2 & 1.933 & 2.371 & 3.272 & 1.246 & 2.141 & 3.323 & 1.380 & 1.719 & 2.853 \\
\hline A3 & 1.552 & 1.719 & 2.954 & 1.000 & 1.246 & 1.552 & 1.552 & 2.141 & 2.954 \\
\hline A4 & 2.408 & 3.272 & 4.514 & 1.000 & 1.552 & 1.933 & 1.552 & 2.371 & 3.680 \\
\hline A5 & 2.954 & 3.936 & 5.165 & 1.246 & 2.408 & 2.667 & 1.246 & 1.933 & 2.141 \\
\hline A6 & 1.719 & 2.954 & 3.936 & 1.246 & 1.552 & 2.667 & 1.246 & 1.552 & 3.323 \\
\hline A7 & 1.904 & 3.160 & 4.210 & 1.552 & 2.408 & 2.954 & 1.246 & 2.408 & 2.667 \\
\hline A8 & 2.371 & 3.743 & 4.663 & 1.719 & 2.853 & 3.160 & 1.933 & 2.141 & 3.272 \\
\hline
\end{tabular}

Table 9. Normalized fuzzy decision matrix

\begin{tabular}{|c|c|c|c|c|c|c|c|c|c|}
\hline & \multicolumn{9}{|c|}{ Criteria } \\
\cline { 2 - 11 } & \multicolumn{3}{|c|}{$\mathrm{C}_{1}(\mathrm{Max})$} & \multicolumn{3}{c|}{$\mathrm{C}_{2}(\mathrm{Max})$} & \multicolumn{3}{c|}{$\mathrm{C}_{3}(\mathrm{Max})$} \\
\hline Alternative & $\mathrm{l}$ & $\mathrm{m}$ & $\mathrm{u}$ & $\mathrm{l}$ & $\mathrm{m}$ & $\mathrm{u}$ & $\mathrm{l}$ & $\mathrm{m}$ & $\mathrm{u}$ \\
\hline $\mathrm{A} 1$ & 0.064 & 0.188 & 0.510 & 0.044 & 0.069 & 0.248 & 0.633 & 0.863 & 0.939 \\
\hline $\mathrm{A} 2$ & 0.000 & 0.244 & 0.435 & 0.044 & 0.130 & 0.248 & 0.548 & 0.678 & 0.863 \\
\hline $\mathrm{A} 3$ & 0.144 & 0.236 & 0.425 & 0.000 & 0.100 & 0.206 & 0.000 & 0.025 & 0.213 \\
\hline $\mathrm{A} 4$ & 0.064 & 0.099 & 0.358 & 0.390 & 0.569 & 0.692 & 0.213 & 0.362 & 0.548 \\
\hline $\mathrm{A} 5$ & 0.564 & 0.822 & 1.000 & 0.248 & 0.390 & 0.569 & 0.548 & 0.758 & 0.863 \\
\hline $\mathrm{A} 6$ & 0.099 & 0.358 & 0.564 & 0.707 & 0.818 & 1.000 & 0.025 & 0.213 & 0.362 \\
\hline $\mathrm{A} 7$ & 0.166 & 0.401 & 0.667 & 0.569 & 0.692 & 0.869 & 0.124 & 0.296 & 0.472 \\
\hline $\mathrm{A} 8$ & 0.271 & 0.473 & 0.767 & 0.707 & 0.835 & 1.000 & 0.693 & 0.809 & 1.000 \\
\hline
\end{tabular}


End of Table 9

\begin{tabular}{|c|c|c|c|c|c|c|c|c|c|}
\hline & \multicolumn{3}{|c|}{$\mathrm{C}_{4}(\mathrm{Min})$} & \multicolumn{3}{|c|}{$\mathrm{C}_{5}(\mathrm{Max})$} & \multicolumn{3}{|c|}{$\mathrm{C}_{6}$ (Max) } \\
\hline Alternative & 1 & $\mathrm{~m}$ & $\mathrm{u}$ & 1 & $\mathrm{~m}$ & $\mathrm{u}$ & 1 & $\mathrm{~m}$ & $\mathrm{u}$ \\
\hline A1 & 0.520 & 0.867 & 1.000 & 0.314 & 0.491 & 0.581 & 0.064 & 0.099 & 0.358 \\
\hline A2 & 0.600 & 0.941 & 0.941 & 0.000 & 0.079 & 0.314 & 0.144 & 0.188 & 0.425 \\
\hline A3 & 0.531 & 0.726 & 0.867 & 0.085 & 0.184 & 0.385 & 0.000 & 0.028 & 0.298 \\
\hline A4 & 0.531 & 0.827 & 0.867 & 0.000 & 0.037 & 0.314 & 0.064 & 0.138 & 0.358 \\
\hline A5 & 0.000 & 0.295 & 0.531 & 0.184 & 0.241 & 0.491 & 0.358 & 0.564 & 0.822 \\
\hline A6 & 0.531 & 0.827 & 0.867 & 0.132 & 0.184 & 0.436 & 0.064 & 0.188 & 0.358 \\
\hline A7 & 0.000 & 0.295 & 0.531 & 0.385 & 0.697 & 0.890 & 0.099 & 0.358 & 0.564 \\
\hline \multirow[t]{2}{*}{ A8 } & 0.000 & 0.295 & 0.531 & 0.534 & 0.809 & 1.000 & 0.564 & 0.822 & 1.000 \\
\hline & \multicolumn{3}{|c|}{$\mathrm{C}_{7}(\mathrm{Max})$} & \multicolumn{3}{|c|}{$\mathrm{C}_{8}$ (Min) } & \multicolumn{3}{|c|}{$\mathrm{C}_{9}(\mathrm{Max})$} \\
\hline Alternative & 1 & $\mathrm{~m}$ & $\mathrm{u}$ & 1 & $\mathrm{~m}$ & $\mathrm{u}$ & 1 & $\mathrm{~m}$ & $\mathrm{u}$ \\
\hline $\mathrm{A} 1$ & 0.000 & 0.097 & 0.388 & 0.000 & 0.574 & 0.794 & 0.000 & 0.282 & 0.853 \\
\hline $\mathrm{A} 2$ & 0.106 & 0.227 & 0.476 & 0.133 & 0.574 & 0.908 & 0.055 & 0.194 & 0.660 \\
\hline A3 & 0.000 & 0.046 & 0.388 & 0.794 & 0.908 & 1.000 & 0.126 & 0.368 & 0.702 \\
\hline A4 & 0.237 & 0.476 & 0.820 & 0.652 & 0.794 & 1.000 & 0.126 & 0.462 & 1.000 \\
\hline A5 & 0.388 & 0.660 & 1.000 & 0.378 & 0.475 & 0.908 & 0.000 & 0.282 & 0.368 \\
\hline A6 & 0.046 & 0.388 & 0.660 & 0.378 & 0.794 & 0.908 & 0.000 & 0.126 & 0.853 \\
\hline A7 & 0.097 & 0.445 & 0.736 & 0.271 & 0.475 & 0.794 & 0.000 & 0.478 & 0.584 \\
\hline A8 & 0.227 & 0.607 & 0.861 & 0.194 & 0.309 & 0.732 & 0.282 & 0.368 & 0.832 \\
\hline
\end{tabular}

Table 10. Weighted normalized fuzzy decision matrix

\begin{tabular}{|c|c|c|c|c|c|c|c|c|c|}
\hline & \multicolumn{9}{|c|}{ Criteria } \\
\cline { 2 - 11 } & \multicolumn{3}{|c|}{$\mathrm{C} 1$} & \multicolumn{3}{c|}{$\mathrm{C} 2$} & \multicolumn{3}{c|}{ C3 } \\
\hline Alternative & $\mathrm{l}$ & $\mathrm{m}$ & $\mathrm{u}$ & $\mathrm{l}$ & $\mathrm{m}$ & $\mathrm{u}$ & $\mathrm{l}$ & $\mathrm{m}$ & $\mathrm{u}$ \\
\hline A1 & 0.296 & 0.330 & 0.420 & 0.239 & 0.245 & 0.286 & 0.273 & 0.311 & 0.324 \\
\hline A2 & 0.278 & 0.346 & 0.399 & 0.239 & 0.259 & 0.286 & 0.259 & 0.280 & 0.311 \\
\hline A3 & 0.318 & 0.343 & 0.396 & 0.229 & 0.252 & 0.276 & 0.167 & 0.171 & 0.203 \\
\hline A4 & 0.296 & 0.305 & 0.377 & 0.319 & 0.360 & 0.388 & 0.203 & 0.227 & 0.259 \\
\hline A5 & 0.435 & 0.506 & 0.556 & 0.286 & 0.319 & 0.360 & 0.259 & 0.294 & 0.311 \\
\hline A6 & 0.305 & 0.377 & 0.435 & 0.391 & 0.417 & 0.458 & 0.171 & 0.203 & 0.227 \\
\hline A7 & 0.324 & 0.389 & 0.463 & 0.360 & 0.388 & 0.428 & 0.188 & 0.216 & 0.246 \\
\hline A8 & 0.353 & 0.409 & 0.491 & 0.391 & 0.421 & 0.458 & 0.283 & 0.302 & 0.334 \\
\hline & & C4 & & & C5 & & & C6 & \\
\hline Alternative & 1 & $\mathrm{~m}$ & $\mathrm{u}$ & 1 & $\mathrm{~m}$ & $\mathrm{u}$ & 1 & $\mathrm{~m}$ & $\mathrm{u}$ \\
\hline A1 & 0.150 & 0.184 & 0.197 & 0.084 & 0.095 & 0.101 & 0.057 & 0.058 & 0.072 \\
\hline A2 & 0.158 & 0.191 & 0.191 & 0.064 & 0.069 & 0.084 & 0.061 & 0.063 & 0.076 \\
\hline A3 & 0.151 & 0.170 & 0.184 & 0.069 & 0.075 & 0.088 & 0.053 & 0.055 & 0.069 \\
\hline A4 & 0.151 & 0.180 & 0.184 & 0.064 & 0.066 & 0.084 & 0.057 & 0.061 & 0.072 \\
\hline A5 & 0.099 & 0.128 & 0.151 & 0.075 & 0.079 & 0.095 & 0.072 & 0.083 & 0.097 \\
\hline A6 & 0.151 & 0.180 & 0.184 & 0.072 & 0.075 & 0.091 & 0.057 & 0.063 & 0.072 \\
\hline A7 & 0.099 & 0.128 & 0.151 & 0.088 & 0.108 & 0.120 & 0.058 & 0.072 & 0.083 \\
\hline A8 & 0.099 & 0.128 & 0.151 & 0.098 & 0.115 & 0.127 & 0.083 & 0.097 & 0.106 \\
\hline
\end{tabular}


End of Table 10

\begin{tabular}{|c|c|c|c|c|c|c|c|c|c|}
\hline & \multicolumn{3}{|c|}{ C7 } & \multicolumn{3}{c|}{ C8 } & \multicolumn{3}{c|}{ C9 } \\
\hline Alternative & $\mathrm{l}$ & $\mathrm{m}$ & $\mathrm{u}$ & $\mathrm{l}$ & $\mathrm{m}$ & $\mathrm{u}$ & $\mathrm{l}$ & $\mathrm{m}$ & $\mathrm{u}$ \\
\hline $\mathrm{A} 1$ & 0.048 & 0.052 & 0.066 & 0.035 & 0.055 & 0.062 & 0.024 & 0.031 & 0.044 \\
\hline $\mathrm{A} 2$ & 0.053 & 0.058 & 0.070 & 0.039 & 0.055 & 0.066 & 0.025 & 0.029 & 0.040 \\
\hline $\mathrm{A} 3$ & 0.048 & 0.050 & 0.066 & 0.062 & 0.066 & 0.069 & 0.027 & 0.033 & 0.041 \\
\hline $\mathrm{A} 4$ & 0.059 & 0.070 & 0.086 & 0.057 & 0.062 & 0.069 & 0.027 & 0.035 & 0.048 \\
\hline A5 & 0.066 & 0.079 & 0.095 & 0.048 & 0.051 & 0.066 & 0.024 & 0.031 & 0.033 \\
\hline $\mathrm{A} 6$ & 0.050 & 0.066 & 0.079 & 0.048 & 0.062 & 0.066 & 0.024 & 0.027 & 0.044 \\
\hline $\mathrm{A} 7$ & 0.052 & 0.069 & 0.082 & 0.044 & 0.051 & 0.062 & 0.024 & 0.035 & 0.038 \\
\hline A8 & 0.058 & 0.076 & 0.088 & 0.041 & 0.045 & 0.060 & 0.031 & 0.033 & 0.044 \\
\hline
\end{tabular}

Table 11. Border approximation area matrix (BAA)

\begin{tabular}{|c|c|c|c|c|c|c|c|c|c|}
\hline \multirow{3}{*}{ BBA } & \multicolumn{9}{|c|}{ Criteria } \\
\hline & \multicolumn{3}{|c|}{$\mathrm{C} 1$} & \multicolumn{3}{|c|}{$\mathrm{C} 2$} & \multicolumn{3}{|c|}{ C3 } \\
\hline & 1 & $\mathrm{~m}$ & $\mathrm{u}$ & 1 & $\mathrm{~m}$ & $\mathrm{u}$ & 1 & $\mathrm{~m}$ & $\mathrm{u}$ \\
\hline \multirow{7}{*}{$\tilde{g}_{\dot{I}}$} & 0.323 & 0.372 & 0.439 & 0.300 & 0.325 & 0.360 & 0.221 & 0.245 & 0.273 \\
\hline & \multicolumn{3}{|c|}{$\mathrm{C} 4$} & \multicolumn{3}{|c|}{ C5 } & \multicolumn{3}{|c|}{ C6 } \\
\hline & 1 & $\mathrm{~m}$ & $\mathrm{u}$ & l & $\mathrm{m}$ & $\mathrm{u}$ & 1 & $\mathrm{~m}$ & $\mathrm{u}$ \\
\hline & 0.129 & 0.159 & 0.173 & 0.076 & 0.084 & 0.098 & 0.062 & 0.068 & 0.080 \\
\hline & \multicolumn{3}{|c|}{$\mathrm{C} 7$} & \multicolumn{3}{|c|}{ C8 } & \multicolumn{3}{|c|}{ C9 } \\
\hline & 1 & $\mathrm{~m}$ & $\mathrm{u}$ & 1 & $\mathrm{~m}$ & $\mathrm{u}$ & 1 & $\mathrm{~m}$ & $\mathrm{u}$ \\
\hline & 0.054 & 0.064 & 0.078 & 0.046 & 0.055 & 0.065 & 0.026 & 0.031 & 0.041 \\
\hline
\end{tabular}

Then, the element values of the matrix $\tilde{Q}$, which denotes the distances of each alternative to the border approximation areas were computed with the help of Equation (13). Finally, the final performance score of each alternative was calculated by implementing Equation (16). Two different defuzzification operations proposed by Božanić et al. (2019) were used, and its mathematical expression is given Equations (17) and (18) are implemented to make defuzzification for the obtained fuzzy values. The final ranking performances of the alternatives are presented in Table 12.

Table 12. Final ranking results of the fuzzy MABAC technique

\begin{tabular}{|c|c|c|c|c|}
\hline Alternative & Defuzzy $\psi_{i}^{1}$ & Rank & Defuzzy $\psi_{i}^{2}$ & Rank \\
\hline A1 & -0.037 & 6 & -0.038 & 6 \\
\hline A2 & -0.066 & 7 & -0.063 & 7 \\
\hline A3 & -0.172 & 8 & -0.176 & 8 \\
\hline A4 & -0.027 & 5 & -0.030 & 5 \\
\hline A5 & 0.149 & 2 & 0.153 & 2 \\
\hline A6 & 0.050 & 3 & 0.054 & 3 \\
\hline A7 & 0.040 & 1 & 0.043 & 4 \\
\hline A8 & 0.225 & 0.225 & 1 \\
\hline
\end{tabular}

Note: Defuzzy $\psi_{i}^{1}$ is computed by using equation 17, Defuzzy $\psi_{i}^{2}$ is computed by using Equation (18). For calculation of Defuzzy $\psi_{i}^{2}$ values, the value of $\lambda$ is accepted as 0.5 . 
To examine the impacts of the $\lambda$ coefficient given in equation 18 applied for defuzzification, a comprehensive examination was performed with different $\lambda$ coefficients $\lambda \in[0.1,0.9]$. The obtained results are given in Table 13.

When Table 13 is evaluated, the ranking results obtained using the different $\lambda$ values from 0.1 to 0.9 are the same as the proposed fuzzy hybrid model's ranking results. In addition to that, the ranking position of the A8 has not changed in other conditions.

Table 13. Analysis of the impacts of the $\lambda$ coefficient on the ranking results

\begin{tabular}{|c|c|c|c|c|c|c|}
\hline & \multicolumn{2}{|c|}{$\lambda=0.1$} & \multicolumn{2}{|c|}{$\lambda=0.2$} & \multicolumn{2}{|c|}{$\lambda=0.3$} \\
\hline & Defuzzy $\psi_{i}^{2}$ & Rank & Defuzzy $\psi_{i}^{2}$ & Rank & Defuzzy $\psi_{i}^{2}$ & Rank \\
\hline A1 & -0.186 & 6 & -0.149 & 6 & -0.112 & 6 \\
\hline A2 & -0.207 & 7 & -0.171 & 7 & -0.135 & 7 \\
\hline A3 & -0.304 & 8 & -0.272 & 8 & -0.240 & 8 \\
\hline A4 & -0.171 & 5 & -0.136 & 5 & -0.101 & 5 \\
\hline A5 & -0.001 & 2 & 0.038 & 2 & 0.076 & 2 \\
\hline A6 & -0.098 & 3 & -0.060 & 3 & -0.022 & 3 \\
\hline A7 & -0.119 & 4 & -0.078 & 4 & -0.038 & 4 \\
\hline \multirow[t]{3}{*}{ A8 } & 0.066 & 1 & 0.105 & 1 & 0.145 & 1 \\
\hline & \multicolumn{2}{|c|}{$\lambda=0.4$} & \multicolumn{2}{|c|}{$\lambda=0.5$} & \multicolumn{2}{|c|}{$\lambda=0.6$} \\
\hline & Defuzzy $\psi_{i}^{2}$ & Rank & Defuzzy $\psi_{i}^{2}$ & Rank & Defuzzy $\psi_{i}^{2}$ & Rank \\
\hline A1 & -0.075 & 6 & -0.038 & 6 & -0.001 & 6 \\
\hline A2 & -0.099 & 7 & -0.063 & 7 & -0.027 & 7 \\
\hline A3 & -0.208 & 8 & -0.176 & 8 & -0.144 & 8 \\
\hline A4 & -0.065 & 5 & -0.030 & 5 & 0.006 & 5 \\
\hline A5 & 0.115 & 2 & 0.153 & 2 & 0.192 & 2 \\
\hline A6 & 0.016 & 3 & 0.054 & 3 & 0.092 & 3 \\
\hline A7 & 0.003 & 4 & 0.043 & 4 & 0.084 & 4 \\
\hline \multirow[t]{3}{*}{ A8 } & 0.185 & 1 & 0.225 & 1 & 0.264 & 1 \\
\hline & \multicolumn{2}{|c|}{$\lambda=0.7$} & \multicolumn{2}{|c|}{$\lambda=0.8$} & \multicolumn{2}{|c|}{$\lambda=0.9$} \\
\hline & Defuzzy $\psi_{i}^{2}$ & Rank & Defuzzy $\psi_{i}^{2}$ & Rank & Defuzzy $\psi_{i}^{2}$ & Rank \\
\hline $\bar{A} 1$ & 0.036 & 6 & 0.07 & 6 & 0.110 & 6 \\
\hline A2 & 0.009 & 7 & 0.04 & 7 & 0.081 & 7 \\
\hline A3 & -0.112 & 8 & -0.08 & 8 & -0.048 & 8 \\
\hline A4 & 0.041 & 5 & 0.08 & 5 & 0.112 & 5 \\
\hline A5 & 0.231 & 2 & 0.27 & 2 & 0.308 & 2 \\
\hline A6 & 0.130 & 3 & 0.17 & 3 & 0.206 & 3 \\
\hline A7 & 0.124 & 4 & 0.16 & 4 & 0.205 & 4 \\
\hline A8 & 0.304 & 1 & 0.34 & 1 & 0.384 & 1 \\
\hline
\end{tabular}




\section{Sensitivity analysis}

A comprehensive sensitivity analysis was performed to make a validation test for the proposed fuzzy integrated MCDM approach. The analysis was made in two-stage. First, by forming 90 different scenarios, the weight values of the criteria were changed, and likely changes in ranking performances of the options were observed. Secondly, the impacts of eliminating each alternative on the final ranking results of the proposed model were examined, and the model's robustness was tested. Thirdly, the ranking results of the proposed model have been compared to the ranking results obtained by using different fuzzy integrated MCDM models.

\subsection{Examining the effects of different weight values on ranking results}

In this phase, we formed different 90 scenarios to examine the impacts of changing of criteria weights on the final ranking of the decision alternatives. Then, we implemented Equations (19), (20), and (21), respectively, to modify the weights of criteria:

$$
\begin{aligned}
& w_{f v}^{1}=w_{p v}^{1}-\left(w_{p v}^{1} \cdot m_{v}\right) ; \\
& w_{n v}^{2}=\frac{\left(1-w_{f v}^{1}\right)}{n-1}+w_{p v}^{2} ; \\
& w_{f v}^{1}+\sum w_{n v}^{2}=1,
\end{aligned}
$$

where, $w_{f v}^{1}$ denotes the new value of the modified weight of $j^{\text {th }}$ factor, $w_{p v}^{1}$ is the previous values of the criterion, $m_{v}$ is the modification degree in terms of percentage (i.e., $10 \%$, $20 \%, \ldots, 100 \%)$. Also, $w_{n v}^{2}$ symbolizes new values of remaining factors, $n$ is the number of factors, $w_{p v}^{2}$ is the previous values of the remaining criteria.

Next, we implemented the proposed approach to test the validation of th suggested model, and we reached the results presented in Figure 3. As seen in Figure 3, A8 has remained in the same ranking position for 88 scenarios (0.978), and the second-best option has remained in the same ranking position for 86 scenarios (0.956). For all alternatives, the average similarity rate has been computed as 0.883 . Thus, it has been slight changes, which did not change the overall results in the ranking positions of the alternatives.

As a result, the obtained results approve that the proposed model is consistent and stable on a vast scale, and they validated the robustness, effectivity, and applicability of the suggested MCDM framework.

\subsection{Examination of the impacts of the rank reversal problem on the ranking results}

In literature, it is suggested to examine the impacts of adding or eliminating a decision alternative to test the consistency of the model (Nedeljković et al., 2021). It is performed to measure the resistance of the proposed model to the rank reversal problem. Also, Ecer (2021) proposes to analyze the scenarios identified based on eliminating the most insignificant (undesirable) alternative (Ecer, 2021). For this purpose, we formed 7 different scenarios by eliminating the worst alternative and examined the changes in the ranking results. According to the ranking results of the proposed model, options were ranked as A8 $>$ A5 $>$ A6 $>$ A7 $>$ A4 $>$ $\mathrm{A} 1>\mathrm{A} 2>\mathrm{A} 3$. As is seen, the most effective alternative is A8, and the worst option is A3. 
In the first scenario, we eliminated the A3 alternative, and we continued to eliminate the worst alternative by considering obtained ranking results in the following scenarios. The obtained results are presented in Table 14.

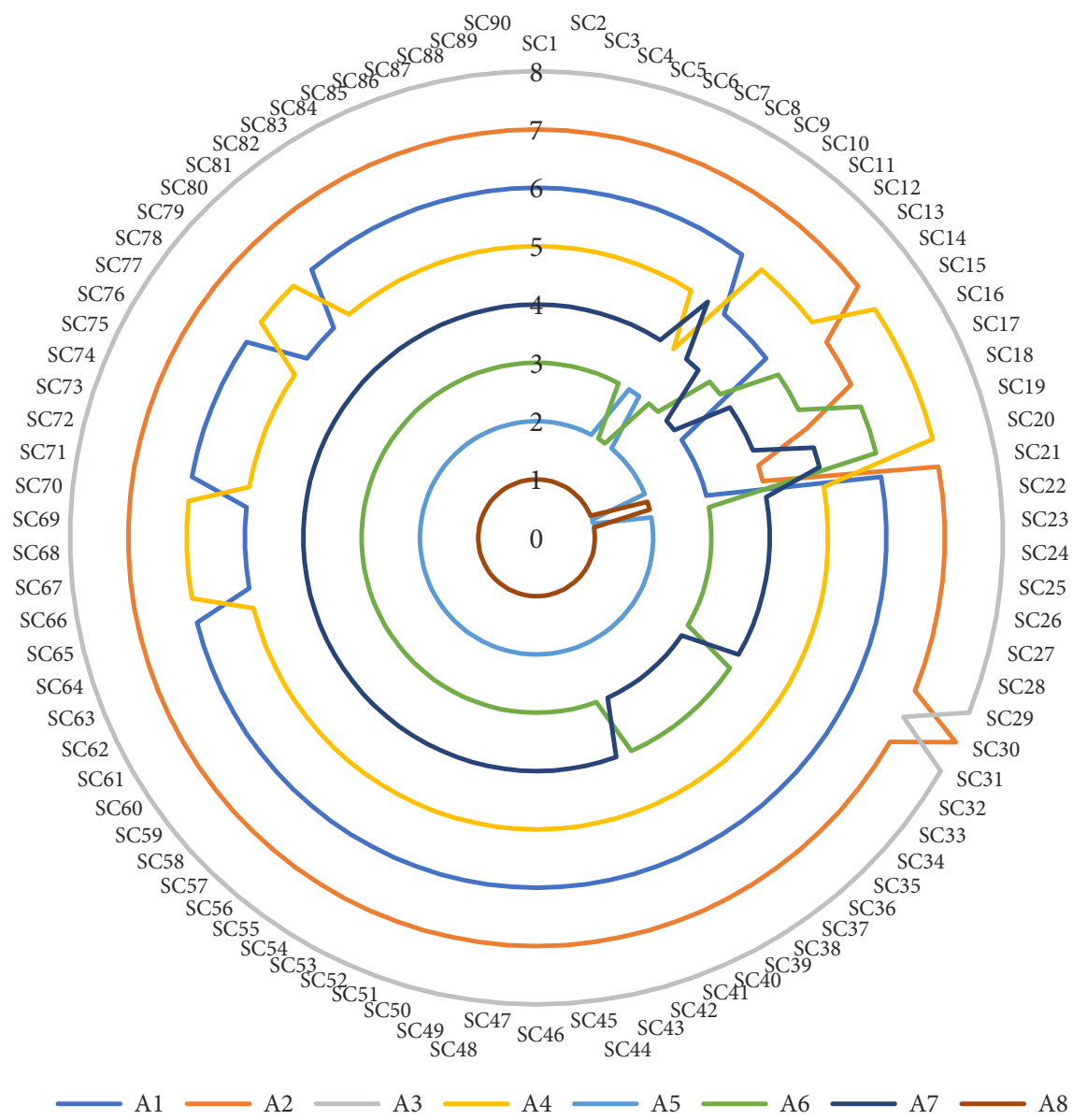

Figure 3. Ranking the alternatives for modified weights of criteria

Table 14. The new ranking of the alternatives according to the scenarios

\begin{tabular}{|l|l|}
\hline \multicolumn{1}{|c|}{ Scenario } & \multicolumn{1}{c|}{ Ranking } \\
\hline Orjinal & A8 $>$ A5 $>$ A6 $>$ A7 $>$ A4 $>$ A1 $>$ A2 $>$ A3 \\
\hline Scenario-1 & A8 $>$ A5 $>$ A6 $>$ A7 $>$ A4 $>$ A1 $>$ A2 \\
\hline Scenario-2 & A8 $>$ A5 $>$ A6 $>$ A7 $>$ A4 $>$ A1 \\
\hline Scenario-3 & A8 $>$ A5 $>$ A6 $>$ A7 $>$ A4 \\
\hline Scenario-4 & A8 $>$ A5 $>$ A6 $>$ A7 \\
\hline Scenario-5 & A8 $>$ A5 $>$ A6 \\
\hline Scenario-6 & A8 $>$ A5 \\
\hline Scenario-7 & A8 \\
\hline
\end{tabular}


When we evaluate the alternatives given in Table 14, A8 has remained the best option for all scenarios. Thus, these results approve the robustness and validity of the proposed model. As a result, the proposed model can be accepted as maximally stable and consistent.

\subsection{Comparison of the proposed hybrid model with the various fuzzy MCDM techniques}

The results obtained by using the proposed hybrid fuzzy model have been compared to the results obtained by implemented various fuzzy MCDM techniques, and the obtained comparison results are given in Figure 3. In accordance with the comparison results, for some fuzzy MCDM techniques, which are implemented in the paper, such as FMOORA (Akkaya et al., 2015), F-COPRAS (Fouladgar et al., 2012), FWASPAS (Turskis et al., 2015), FMAIRCA, (Pamucar et al., 2018) and FMARCOS (Stankovic et al., 2020) A8 is also determined the best alternative.

As seen in Figure 4, being A8 is the best alternative proves that the hybrid fuzzy MCDM model is validated, and these results are accordant with the results of the integrated fuzzy approach. It can also be accepted as an extraordinary situation that the ranking of the decision alternatives by using both the proposed model and F-MOORA is entirely the same. The correlation coefficient between the ranking results of the proposed model and the ranking results obtained by using other implemented approaches was computed by applying Spearman's correlation coefficient approach (Pamucar \& Božanić, 2019), and the obtained results are given in Table 15 .

When the results in Table 15 are evaluated, a high correlation between all implemented MCDM frameworks by 0.98 on average proves that the proposed model is a maximally stable and robust technique. As a result, staying A8 in the same ranking position for all scenarios and implemented techniques has validated the proposed fuzzy integrated MCDM approach's applicability.

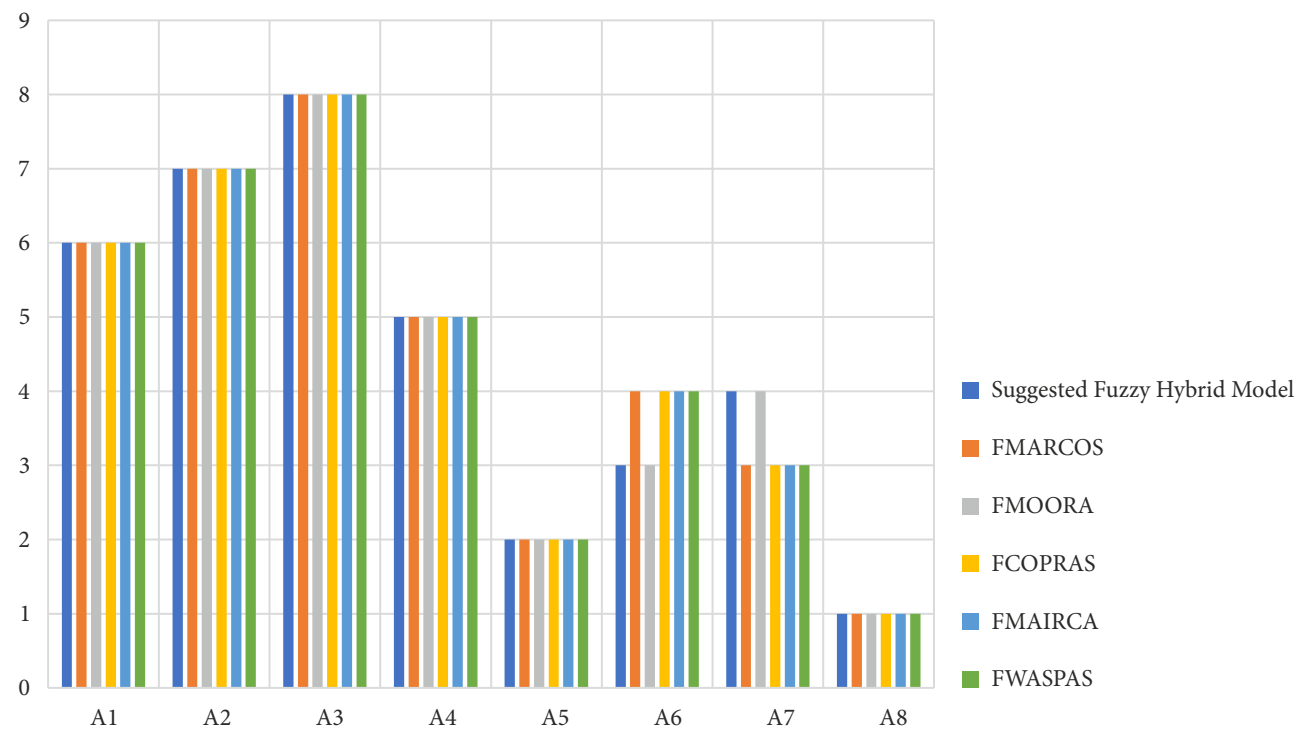

Figure 4. Ranking of the alternatives with different MCDM techniques 
Table 15. Spearman's correlations (SSC)

\begin{tabular}{|c|c|c|c|c|c|c|}
\hline & $\begin{array}{c}\text { Suggested } \\
\text { Fuzzy } \\
\text { Hybrid } \\
\text { Model }\end{array}$ & FMARCOS & FMOORA & FCOPRAS & FMAIRCA & FWASPAS \\
\hline $\begin{array}{l}\text { Suggested Fuzzy } \\
\text { Hybrid Model }\end{array}$ & 1 & $0.976^{\star *}$ & $1.000^{* *}$ & $0.976^{\star *}$ & $0.976^{\star \star}$ & $0.976^{\star *}$ \\
\hline FMARCOS & & 1 & $0.976^{\star *}$ & $1.000^{\star \star}$ & $1.000^{\star *}$ & $1.000^{\star *}$ \\
\hline FMOORA & & & 1 & $0.976^{\star \star}$ & $0.976^{\star \star}$ & $0.976^{\star *}$ \\
\hline FCOPRAS & & & & 1 & $1.000^{\star *}$ & $1.000^{\star *}$ \\
\hline FMAIRCA & & & & & 1 & $1.000^{\star *}$ \\
\hline FWASPAS & & & & & & 1 \\
\hline
\end{tabular}

Note: ${ }^{\star *}$ Correlation is significant at the 0.01 level (2-tailed).

\section{Results and discussions}

The selection of an appropriate logistics village depends on a realistic and reasonable assessment of many complicated and conflicting criteria and overcome existing ambiguities apart from the knowledge and experiences of the decision-makers. There are many dynamics in an evaluation process, and they have to take into consideration by decision-makers. Because of that, it is not an easy business for decision-makers, and any mistake can cause vital problems for logistics companies. For example, a mis choice can cause to reduce profits, productivity, effectiveness, and performance can also cause increased risks and costs. Hence, these selection processes are susceptible, and decision-makers should be more careful to make the right decisions. More importantly, a practical, applicable and robust MCDM framework should be used to solve these kinds of decision-making problems effectively. The current paper proposes a powerful, robust, and applicable decision-making model to deal with many uncertainties and complex situations. As indicated in Section 2, we noticed severe and surprising gaps in the existing literature, and the related industry needs a reliable MCDM framework to solve this decision-making problem. Due to some structural problems and drawbacks, the previous papers' models and techniques are not sufficiently reliable. By keeping in mind these requirements, we propose a maximally reliable mathematical tool. Then we applied the proposed model and obtained results summarized as follows.

When we evaluate the results on identifying the criteria weights, the most significant criterion is determined as $\mathrm{C}_{1} \mathrm{GNP}$ of the City $(000 \mathrm{TL})$. It is quite meaningful and reasonable, as logistics companies want to carry out their business activities in a city with higher Gross National Products (GNP). It makes it possible to increase profits and turnover of the firm because it can increase the number of potential customers. Moreover, customers may accept pay more reasonable prices for logistics services in these kinds of cities. $\mathrm{C}_{2}$ is the second significant criterion. Also, logistics companies want to be concerned with many businesses, and it is expected to be located in a logistics village that provides more options. remainders ranked as $\mathrm{C}_{3}>\mathrm{C}_{4}>\mathrm{C}_{5}>\mathrm{C}_{6}>\mathrm{C}_{7}>\mathrm{C}_{8}>\mathrm{C}_{9}$. The overall results show that logistics companies want more options to form orderly relations and connections between their customers. 
If the number of customers is high and they have more gains, they can help logistics firms make more earnings. It proves that the potential advantages of a logistics village concerning customer relations are more crucial than operational requirements such as $\mathrm{C}_{4}$ "distance to nearest port" and $\mathrm{C}_{8}$ distance to the nearest airport. Logistics companies think that they can solve logistical and operational problems depending on their competency more easily.

Next, we evaluated the ranking results of the proposed model; A8 is determined as the best option. It is reasonable, as it responds to many requirements of logistics companies. First of all, there are many industries and companies in this city, and its location is suitable to reach many geographical areas. Especially, it can serve many companies exporting goods to EU countries, Russia and north countries, and Middle East countries. Secondly, logistic companies prefer logistics villages located in developing cities instead of logistic centers, which are available in bigger and developed cities, as they want to obtain more benefits in these kinds of cities. Remain alternatives are ranked as A5 $>$ A6 $>$ A7 $>$ A4 $>$ A1 $>$ A2 $>$ A3 .

After the proposed model was applied, a comprehensive sensitivity analysis was performed to test the suggested fuzzy model and its results. The analysis results prove that both the obtained results and the proposed fuzzy model are appropriate for solving these problems. Implemented all scenarios and different fuzzy MCDM techniques have given almost the same results. Finally, the suggested fuzzy integrated approach can be applied to these kinds of highly complex decision-making problems. The results obtained by using the model are accurate, realistic, and applicable when the sensitivity analysis results are considered.

As a result, the proposed model is an applicable, robust, and powerful mathematical model that can be implemented to solve decision-making problems encountered in the logistics industry. Also, the suggested MCDM framework can be applied to solve decision-making problems in various fields such as engineering, business, supply chain management, etc.

\section{Practical and managerial implication}

The current paper proposes a novel and integrated powerful mathematical tool for solving many decision-making problems. The proposed model is maximally consistent, and it is not affected the rank reversal problem. Thus, it provides a more reliable and flexible evaluation environment for decision-makers. Moreover, it eliminates many structural problems and gaps existing in the literature. First, decision-makers do not suffer from undesirable and excessive evaluations since the current approach can easily tolerate those. Keeping in mind these advantages, logistics companies can select a more reasonable logistics village alternative and create a more improved logistics system while increasing profits and productivity and reducing risks and costs of logistics operations. In addition, practitioners can implement it easily without advanced mathematical knowledge, as it has a good and practical algorithm. Because of that, it can be applied by practitioners to solve decision-making problems encountered in the logistics industry. Besides, it can be inspirational for authors who perform future works on this issue. In the current paper, the set of criteria were identified together with highly experienced and had extensive knowledge of the related industry by following a methodological frame. These criteria are updated and fit with real-life decision-making problems and requirements. Both practitioners and authors also consider them to evaluate real-life decision-making problems encountered in the logistics industry. 


\section{Conclusions}

Logistics village selection is crucial for logistics companies and operators because it can affect a logistics company's productivity, effectiveness, and performance. The selection of the appropriate logistics village is a highly complicated and time-consuming decision-making problem decision-making are many conflicting criteria, which can affect the assessment process. Therefore, decision-makers need a methodological frame to solve this decision-making problem. This paper proposes a hybrid fuzzy MCDM model because solving this problem is impossible without considering uncertainties existing in an evaluation process.

The proposed fuzzy model consists of the IMF SWARA technique and the F MABAC method. The IMF SWARA technique has been implemented for calculating the weights of the criteria, and the F MABAC has been applied to determine the ranking performances of the decision alternatives. Although the current paper and proposed MCDM framework have many valuable advantages, they have some limitations. For instance, selecting the right decision makers is crucial for researchers, and they have to be more careful about selecting appropriate experts. Hence, they should determine a set of criteria for determining the proper experts. In addition, the current paper presents some recommendations to authors who perform future works as follows. New criteria can be added into the scope of the evaluation process depending on new developments occurring in the current field. Also, the proposed model can be extended with the help of type 2 neutrosophic fuzzy sets and intuitionistic fuzzy sets. Moreover, it can be integrated with different MCDM frameworks, and a novel hybrid technique can be formed with the help of the proposed MCDM model.

\section{References}

Akkaya, G., Turanoglu, B., \& Oztas, S. (2015). An integrated fuzzy AHP and fuzzy MOORA approach to the problem of industrial engineering sector choosing. Expert Systems with Applications, 42, 9565-9573. https://doi.org/10.1016/j.eswa.2015.07.061

Aksoy, O., \& Ozyürük, B. (2015). The importance of freight villages: An implementation in TCDD. Applied Mathematical Modelling, 39(19), 6043-6049. https://doi.org/10.1016/j.apm.2015.01.034

Altuntaş, V. C., \& Tuna, O. (2015). The prioritisation of service dimensions in logistics centres: a fuzzy quality function deployment methodology. International Journal of Logistics Research and Applications, 19, 1-22. https://doi.org/10.1080/13675567.2015.1008438

Arikan, F. (2012). Freight villages and an application [Master Thesis]. Bahçeșehir University, Istanbul.

Awasthi, A., Chauhan, S. S., \& Goyal, S. K. (2011). A multi-criteria decision making approach for location planning for urban distribution centers under uncertainty. Mathematical and Computer Modelling, 53, 98109. https://doi.org/10.1016/j.mcm.2010.07.023

Biswas, T. K., \& Das, M. C. (2019). Selection of commercially available electric vehicle using fuzzy AHP-MABAC. Journal of The Institution of Engineers (India): Series C, 100, 531-537. https://doi.org/10.1007/s40032-018-0481-3

Bobar, Z., Božanić, D., Djurić, K., \& Pamučar, D. (2020). Ranking and assessment of the efficiency of social media using the fuzzy AHP-Z number model - Fuzzy MABAC. Acta Polytechnica Hungarica, 17(3), 64. https://doi.org/10.12700/APH.17.3.2020.3.3

Boile, M., Theofanis, S., \& Gilbert, P. (2010). Feasibility of Freight Villages in the NYMTC Region (pp. 11-15). The State University of New Jersey. 
Bottero, M., Dalla Chiara, B., \& Deflorio, F. (2013). Wireless sensor networks for traffic monitoring in a logistic centre. Transportation Research Part C: Emerging Technologies, 26, 99-124. https://doi.org/10.1016/j.trc.2012.06.008

Božanić, D., Tešić, D., \& Kočić, J. (2019). Multi-criteria FUCOM - Fuzzy MABAC model for the selection of location for construction of single-span bailey bridge. Decision Making: Applications in Management and Engineering, 2(1), 132-146. https://doi.org/10.31181/dmame1901132b

Büyüközkan, G., Mukul, E., \& Kongar, E. (2020). Health tourism strategy selection via SWOT analysis and integrated hesitant fuzzy linguistic AHP-MABAC approach. Socio-Economic Planning Sciences, 74, 100929. https://doi.org/10.1016/j.seps.2020.100929

Can, A. M. (2012). Selection the location of freight village in Samsun with Multi-Criteria Decision Making [Master Thesis]. Erciyes University, Kayseri.

Chen, K. H., Liao, C. N., \& Wu, L. C. (2014). A selection model to logistic centers based on TOPSIS and MCGP methods: The case of airline industry. Journal of Applied Mathematics, 2014, 470128. https://doi.org/10.1155/2014/470128

Chen, Y., \& Qu, L. (2006). Evaluating the selection of logistics centre location using fuzzy MCDM model based on entropy weight. In 6th World Congress on Intelligent Control and Automation (pp. 7128-7132), Dalian, China. IEEE. https://doi.org/10.1109/WCICA.2006.1714468

Cristea, M., \& Cristea, C. (2016). A multi-criteria decision-making approach used for the selection of a logistics center location. Annals of the University of Oradea, 24(15). https://doi.org/10.15660/AUOFMTE.2016-1.3202

Dablanc, L. (2007). Goods transport in large European cities: Difficult to organize, difficult to modernize. Transportation Research Part A: Policy and Practice, 41, 280-285. https://doi.org/10.1016/j.tra.2006.05.005

Demiroğlu, Ş., \& Elener, A. (2014). Küresel lojistik köyleri ve Türkiyede kurulması planlanan lojistik köy bölgelerinin ÇKKV yöntemleriyle belirlenmesi. Dumlupınar University Journal of Social Sciences, 42, 189-202.

Ecer, F. (2020). Çok kriterli karar verme geçmişten günümüze kapsamlı bir yaklaşım. Seçkin Yayıncılık.

Ecer, F. A. (2021). A consolidated MCDM framework for performance assessment of battery electric vehicles based on ranking strategies. Renewable and Sustainable Energy Reviews, 143, 110916. https://doi.org/10.1016/j.rser.2021.110916

Elgu, M., \& Elitaş, C. (2011). Yerel ulusal ve uluslararası taşıma ve ticaret açısından lojistik köy merkezlerinin seçiminde bir model önerisi. Celal Bayar Üniversitesi Sosyal Bilimler Dergisi, Celal Bayar Üniversitesi Manisa, 9.

Erkayman, B., Gündoğar, E., Akkaya, G., \& İpek, M. (2011). A fuzzy topsis approach for logistics center location selection. Journal of Business Case Studies, 7(3), 49-55.

https://doi.org/10.19030/jbcs.v7i3.4263

Fagaraşan, M., \& Cristea, C. (2015). Logistic center location: selection using multi-criteria decision making. In Proceedings of the Annual Sessions of Scientific Papers "IMT Oradea" (pp. 193-198).

Fouladgar, M. M., Yazdani, C. A., \& Zavadskas, E. (2012). Risk evaluation of tunneling projects. Archives of Civil and Mechanical Engineering, 12, 1-12. https://doi.org/10.1016/j.acme.2012.03.008

Gong, J.-W., Li, Q., Yin, L., \& Liu, H.-C. (2019). Undergraduate teaching audit and evaluation using an extended MABAC method under q-rung orthopair fuzzy environment. International Journal of Intelligent Systems, 35(12), 1912-1933. https://doi.org/10.1002/int.22278

Goseiri, K., \& Lessan, J. (2008). Location selection for logistic centers using a two-step Fuzzy-AHP and ELECTRE Method. In 9th Asia Pacific Industrial Engineering \& Management Systems Conference, Bali, Indonesia.

Hamamcioğglu, C., \& Oguztimur, S. (2017). The comparison of basic transportation infrastructure and freight villages' locations between Germany and Turkey. Journal of Traffic and Transportation Engineering, 5, 77-92. https://doi.org/10.17265/2328-2142/2017.02.003 
Jokić, Ž., Božanić, D., \& Pamučar, D. (2021). Selection of fire position of mortar units using LBWA and Fuzzy MABAC model. Operational Research in Engineering Sciences: Theory and Applications, 4(1), 115-135. https://doi.org/10.31181/oresta20401156j

Kayikci, Y. (2010). A conceptual model for intermodal freight logistics centre location decisions. Procedia - Social and Behavioral Sciences, 2(3), 6297-6311. https://doi.org/10.1016/j.sbspro.2010.04.039

Kersuliene, V., Zavadskas, E., \& Turskis, Z. (2010). Selection of rational dispute resolution method by applying new step-wise weight assessment ratio analysis (SWARA). Journal of Business Economics and Management, 11, 243-258. https://doi.org/10.3846/jbem.2010.12

Kumar, A., \& Anbanandam, R. (2019). Development of social sustainability index for freight transportation system. Journal of Cleaner Production, 210, 77-92. https://doi.org/10.1016/j.jclepro.2018.10.353

Li, Y., Liu, X., \& Chen, Y. (2011). Selection of logistics center location using axiomatic fuzzy set and TOPSIS methodology in logistics management. Expert Systems with Applications, 38, 7901-7908. https://doi.org/10.1016/j.eswa.2010.12.161

Liang, W., Zhao, G., Wu, H., \& Dai, B. (2019). Risk assessment of rockburst via an extended MABAC method under fuzzy environment. Tunnelling and Underground Space Technology, 83, 533-544. https://doi.org/10.1016/j.tust.2018.09.037

Lipscomb, T., Long, S., \& Grasman, S. (2011). Sustainability criteria for inland freight hub location evaluation. In Transportation Research Board Annual Meeting (Paper 11-1847).

Mardani, A., Zavadskas, E., Khalifah, Z., Zakuan, N., Jusoh, A., Nor, K., \& Khoshnoudi, M. (2017). A review of multi-criteria decision-making applications to solve energy management problems: Two decades from 1995 to 2015. Renewable and Sustainable Energy Reviews, 71, 216-256. https://doi.org/10.1016/j.rser.2016.12.053

Mavi, R. K., Goh, M., \& Zarbakhshnia, N. (2017). Sustainable third-party reverse logistic provider selection with fuzzy SWARA and fuzzy MOORA in plastic industry. The International Journal of Advanced Manufacturing Technology, 91, 2401-2418. https://doi.org/10.1007/s00170-016-9880-x

Mihajlović, J., Rajković, P., Petrović, G., \& Ćirić, D. (2019). The selection of the logistics distribution center location based on MCDM methodology in southern and eastern region in Serbia. Operational Research in Engineering Sciences: Theory and Applications, 2(2), 72-85. https://doi.org/10.31181/oresta190247m

Mokhtarian, P. A. (2004). Conceptual analysis of the transportation impacts of B2C E-commerce. Transportation, 31, 257-284. https://doi.org/10.1023/B:PORT.0000025428.64128.d3

Nedeljković, M., Puška, A., Doljanica, S., Virijević Jovanović, S., Brzaković, P., Stević, Ž., \& Marinkovic, D. (2021). Evaluation of rapeseed varieties using novel integrated fuzzy PIPRECIA - Fuzzy MABAC model. PLoS ONE, 16(2), e0246857. https://doi.org/10.1371/journal.pone.0246857

Nguyen, L., \& Notteboom, T. (2017). Public-private partnership model selection for dry port development: An application to Vietnam. World Review of Intermodal Transportation Research, 6, 229-239. https://doi.org/10.1504/WRITR.2017.086208

Organisation for Economic Co-operation and Development. (2020). Report, connecting businesses and consumers during COVID-19: Trade in parcels. https://www.oecd.org/coronavirus

Önden, İ., Acar., A. Z., \& Eldemir, F. (2018). Evaluation of the logistics center locations using a multicriteria spatial approach. Transport, 33(2), 322-334. https://doi.org/10.3846/16484142.2016.1186113

Özceylan, E., Erbaş, M., Tolon, M., Kabak, M., \& Durğut, T. (2016). Evaluation of freight villages: A GIS-based multi-criteria decision analysis. Computers in Industry, 76, 38-52. https://doi.org/10.1016/j.compind.2015.12.003

Ozdemir, S., Keskin, B., Eren, T., \& Oüzcan, E. (2020). Tuürkiyedeki Lojistik Merkezleri Yatırım Önceliklerinin Değerlendirilmesinde (Çok Okçütlü Bir Karar Modeli Önerisi). Demiryolu Muühendisligi, 12, 83-94. https://doi.org/10.47072/demiryolu.722626 
Pamucar, D., \& Božanić, D. (2019). Selection of a location for the development of multimodal logistics center: Application of single-valued neutrosophic MABAC model. Operational Research in Engineering Sciences: Theory and Applications, 2, 55-71. https://doi.org/10.31181/oresta1902039p

Pamucar, D., \& Cirovic, G. (2015). The selection of transport and handling resources in logistics centers using Multi-Attributive Border Approximation area Comparison (MABAC). Expert Systems with Applications, 42, 3016-3028. https://doi.org/10.1016/j.eswa.2014.11.057

Pamucar, D. S., Tarle, S. P., \& Parezanovic, T. (2018). New hybrid multi-criteria decision-making DEMATEL-MAIRCA model: sustainable selection of a location for the development of multimodal logistics centre. Economic Research-Ekonomska Istraživanja, 31(1), 1641-1665.

https://doi.org/10.1080/1331677X.2018.1506706

Peker, I., Bakib, B., Tanyas, \& Ar, I. M. (2016). Logistics center site selection by ANP/BOCR analysis: A case study of Turkey. Journal of Intelligent \& Fuzzy Systems, 30, 2383-2396. https://doi.org/10.3233/IFS-152007

Percin, S. (2018). Evaluating airline service quality using a combined fuzzy decision-making approach. Journal of Air Transport Management, 68, 48-60. https://doi.org/10.1016/j.jairtraman.2017.07.004

Puška, A., Nedeljković, M., Hashemkhani Zolfani, S., \& Pamucar, D. (2021). Application of interval fuzzy logic in selecting a sustainable supplier on the example of agricultural production. Symmetry, 13, 774. https://doi.org/10.3390/sym13050774

ReportLinker (n.d.). Logistics market - Global industry analysis, size, share, growth, trends, and forecast 2018-2026. https://www.reportlinker.com

Sengul, D., \& Cagil, G. (2020). Bulanık SWARA ve bulanık Analitik Hiyerarşi Prosesi yöntemi ile iş degerlemesi. DUJE, 11(3), 965-976. https://doi.org/10.24012/dumf.715363

Stankovic, M., Stevic, Z., Das, D., Subotic, M., \& Pamucar, D. (2020). A new fuzzy MARCOS method for road traffic risk analysis. Mathematics, 8 , 1-17. https://doi.org/10.3390/math8030457

Sun, Y., Zhou, X., Jeyaraj, A., Shang, R.-A., \& Hu, F. (2019). The impact of enterprise social media platforms on knowledge sharing: An affordance lens perspective. Journal of Enterprise Information Management, 32(2), 233-250. https://doi.org/10.1108/JEIM-10-2018-0232

Tanyaş, M., \& Bamyacı, M. (2008). Organize Lojistik Bölgesi Yer Seçimi Problemi için Bir Çok Ölçütlü Karar Verme Modeli: AHP-SAW. In Mersin Sempozyumu, 19-22 Kasım 2009, Mersin.

Tsamboulas, D., \& Kapros, S. (2003). Freight village evaluation under uncertainty with public and private financing. Transport Policy, 10, 141-156. https://doi.org/10.1016/S0967-070X(03)00002-7

Tomić, V., Marinković, D., \& Marković, D. (2014). The selection of logistic centers location using multicriteria comparison: Case Study of the Balkan Peninsula. Acta Polytechnica Hungarica, 11, 10.

Ulutaş, A., Karakuş, C. B., \& Topal, A. (2020). Location selection for logistics center with fuzzy SWARA and CoCoSo methods. Journal of Intelligent \& Fuzzy Systems, 38(4), 4693-4709. https://doi.org/10.3233/JIFS-191400

Unnikrishnan, A., \& Figliozzi, M. A. (2020). A Study of the impact of COVID-19 on home delivery purchases and expenditures (Working Paper). Civil and Environmental Engineering Faculty Publications.

Uyanı, C. (2016). An integrated DEMATEL-Intuitionistic Fuzzy TOPSIS methodology for logistics centers location selection [Master Thesis]. Marmara University.

Uysal, F., \& Gülmez, M. (2014). Fuzzy graph theory and matrix approach application for the selection of logistics centre location in the Mediterranean region of Turkey. Verimlilik Dergisi, 1, 89-104.

Uysal, H. T., \& Yavuz, K. (2014). Selection of logistics centre location via ELECTRE method: a case study in Turkey. International Journal of Business and Social Science, 5(9), 276-289.

Turskis, Z., Zavadskas, E., Antucheviciene, J., \& Kosareva, N. (2015). A hybrid model based on fuzzy AHP and fuzzy WASPAS for construction site selection. International Journal of Computers Communications \& Control, 10(6), 113-123. https://doi.org/10.15837/ijccc.2015.6.2078 
Vlachopoulou, M., Silleos, G., \& Manthou, V. (2001). Geographic information systems in warehouse site selection decisions. International Journal of Production Economics, 71(1-3), 205-212. https://doi.org/10.1016/S0925-5273(00)00119-5

Vrtagić, S., Softić, E., Subotić, M., Stević, Ž., Dordevic, M., \& Ponjavic, M. (2021). Ranking road sections based on MCDM model: New improved fuzzy SWARA (IMF SWARA). Axioms, 10(2), 92. https://doi.org/10.3390/axioms10020092

Wang, S., \& Liu, P. (2007). The evaluation study on location selection of logistics center based on fuzzy AHP and TOPSIS. In International Conference on Wireless Communications, Networking and Mobile Computing (pp. 3779-3782). IEEE. https://doi.org/10.1109/WICOM.2007.935

Ylldırım, Y., \& Önder, E. (2014a). Evaluating potential freight villages in Istanbul using multi criteria decision making techniques. Journal of Logistic Management, 3(1), 1-10.

Ylldırım, Y., \& Önder, E. (2014b). VIKOR method for ranking logistic villages in Turkey. Journal of Management and Economic Research, 23, 293-314. https://doi.org/10.11611/JMER236

Żak, J., \& Weglinski, S. (2014). The selection of the logistics center location based on MCDM/A methodology. Transportation Research Procedia, 3, 555-564. https://doi.org/10.1016/j.trpro.2014.10.034

Zalluhoğlu, A. E., Aracıoğlu, B., \& Bozkurt, S. (2014). Lojistik Köy Kurulumunun Lojistik Hizmet Sağlayıcılar Açısından Değerlendirilmesi: İzmir Örneği. Ege Strategic Research Journal, 2, 81-103. https://doi.org/10.18354/esam.39733

Zarbakhshnia, N., Soleimani, H., \& Ghaderi, H. (2018). Sustainable third-party reverse logistics provider evaluation and selection using fuzzy SWARA and developed Fuzzy COPRAS in the presence of risk criteria. Applied Soft Computing, 65, 307-319. https://doi.org/10.1016/j.asoc.2018.01.023

Zhang, H., Wei, G., \& Chen, X. (2021). CPT-MABAC method for spherical fuzzy multiple attribute group decision making and its application to green supplier selection. Journal of Intelligent \& Fuzzy Systems, 41(1), 1009-1019. https://doi.org/10.3233/JIFS-202954 


\section{APPENDIX}

Table A1. DMs' linguistics evaluations for decision alternatives

\begin{tabular}{|c|c|c|c|c|c|c|c|c|c|}
\hline \multirow[b]{2}{*}{ DM-1 } & \multicolumn{9}{|c|}{ Criteria } \\
\hline & $\mathrm{C} 1$ & $\mathrm{C} 2$ & C3 & C4 & C5 & C6 & C7 & C8 & C9 \\
\hline A1 & $\mathrm{P}$ & EP & MG & $\mathrm{P}$ & EP & EP & EP & $\mathrm{P}$ & $\mathrm{P}$ \\
\hline $\mathrm{A} 2$ & $\mathrm{P}$ & $\mathrm{EP}$ & $\mathrm{M}$ & $\mathrm{EP}$ & $\mathrm{EP}$ & $\mathrm{EP}$ & $\mathrm{EP}$ & $\mathrm{P}$ & $\mathrm{P}$ \\
\hline A3 & $\mathrm{EP}$ & EP & EP & EP & EP & $\mathrm{EP}$ & $\mathrm{EP}$ & $\mathrm{P}$ & $\mathrm{P}$ \\
\hline A4 & EP & MP & $\mathrm{P}$ & EP & EP & EP & $\mathrm{M}$ & $\mathrm{P}$ & $\mathrm{P}$ \\
\hline A5 & MP & $\mathrm{P}$ & $\mathrm{G}$ & $\mathrm{P}$ & $\mathrm{EP}$ & $\mathrm{P}$ & $\mathrm{P}$ & MP & $\mathrm{MP}$ \\
\hline A6 & VP & $\mathrm{G}$ & VP & EP & EP & $\mathrm{EP}$ & VP & $\mathrm{P}$ & $\mathrm{P}$ \\
\hline A7 & VP & $\mathrm{M}$ & VP & $\mathrm{P}$ & $\mathrm{P}$ & VP & VP & MP & MP \\
\hline A8 & VP & G & $\mathrm{G}$ & $\mathrm{P}$ & MP & MP & VP & MP & $\mathrm{M}$ \\
\hline DM-2 & $\mathrm{C} 1$ & $\mathrm{C} 2$ & $\mathrm{C} 3$ & $\mathrm{C} 4$ & C5 & C6 & C7 & C8 & $\mathrm{C} 9$ \\
\hline A1 & VP & VP & $\mathrm{G}$ & $\mathrm{P}$ & $G$ & VP & VP & VP & VP \\
\hline A2 & VP & $\mathrm{P}$ & MG & VP & VP & VP & $\mathrm{M}$ & VP & VP \\
\hline $\mathrm{A} 3$ & VP & VP & VP & VP & VP & VP & VP & VP & VP \\
\hline A4 & VP & $\mathrm{M}$ & MP & VP & VP & VP & $\mathrm{M}$ & VP & $\mathrm{M}$ \\
\hline A5 & $\mathrm{M}$ & MP & VG & MP & VP & MP & MP & $\mathrm{P}$ & $\mathrm{P}$ \\
\hline A6 & $\mathrm{P}$ & VG & $\mathrm{P}$ & VP & VP & VP & $\mathrm{P}$ & VP & VP \\
\hline A7 & $\mathrm{P}$ & MG & $\mathrm{P}$ & MP & $\mathrm{G}$ & $\mathrm{P}$ & $\mathrm{P}$ & $\mathrm{P}$ & $\mathrm{P}$ \\
\hline A8 & $\mathrm{P}$ & $\mathrm{VG}$ & $\mathrm{VG}$ & MP & $\mathrm{M}$ & $\mathrm{M}$ & $\mathrm{P}$ & $\mathrm{P}$ & $\mathrm{MP}$ \\
\hline DM-3 & $\mathrm{C} 1$ & $\mathrm{C} 2$ & C3 & $\mathrm{C} 4$ & C5 & C6 & C7 & $\mathrm{C} 8$ & C9 \\
\hline A1 & MP & MP & $\mathrm{EG}$ & VP & MP & MP & $\mathrm{M}$ & VP & $\mathrm{VP}$ \\
\hline A2 & MP & MP & VG & MP & $M$ & MP & MP & $\mathrm{P}$ & VP \\
\hline $\mathrm{A} 3$ & MP & MP & MP & MP & MP & VP & MP & EP & $\mathrm{M}$ \\
\hline A4 & MP & $G$ & MG & MP & MP & $M$ & MP & EP & VP \\
\hline A5 & $G$ & MG & $\mathrm{G}$ & MG & $\mathrm{M}$ & MG & MG & EP & EP \\
\hline A6 & $\mathrm{M}$ & VG & M & MP & MP & MP & $\mathrm{M}$ & VP & VP \\
\hline A7 & VG & VG & $\mathrm{M}$ & MG & MG & $\mathrm{M}$ & $\mathrm{G}$ & MP & EP \\
\hline $\mathrm{A} 8$ & $M$ & G & VG & MG & $\mathrm{G}$ & $G$ & M & EP & VP \\
\hline DM-4 & $\mathrm{C} 1$ & $\mathrm{C} 2$ & C3 & $\mathrm{C} 4$ & C5 & C6 & C7 & C8 & C9 \\
\hline A1 & VP & VP & $G$ & VP & $\mathrm{G}$ & VP & VP & MP & $\mathrm{MP}$ \\
\hline $\mathrm{A} 2$ & $\mathrm{P}$ & VP & MG & VP & VP & MP & VP & $M$ & $\mathrm{MG}$ \\
\hline A3 & $\mathrm{M}$ & $\mathrm{P}$ & VP & $\mathrm{P}$ & $\mathrm{M}$ & VP & VP & EP & MP \\
\hline A4 & VP & M & MP & VP & VP & VP & VP & $\mathrm{P}$ & M \\
\hline A5 & $\mathrm{M}$ & MP & $\mathrm{M}$ & MP & MG & MP & MP & $\mathrm{P}$ & $\mathrm{P}$ \\
\hline A6 & $\mathrm{P}$ & MG & $\mathrm{P}$ & $\mathrm{VP}$ & MG & $\mathrm{P}$ & $\mathrm{P}$ & MP & MP \\
\hline A7 & $\mathrm{P}$ & MG & $G$ & MP & MP & $\mathrm{P}$ & $\mathrm{P}$ & $\mathrm{P}$ & $\mathrm{P}$ \\
\hline A8 & $\mathrm{VG}$ & $\mathrm{VG}$ & MG & MP & $\mathrm{M}$ & $\mathrm{M}$ & $\mathrm{G}$ & $\mathrm{P}$ & $\mathrm{MP}$ \\
\hline DM-5 & $\mathrm{C} 1$ & $\mathrm{C} 2$ & $\mathrm{C} 3$ & $\mathrm{C} 4$ & C5 & C6 & C7 & $\mathrm{C} 8$ & C9 \\
\hline A1 & $\mathrm{M}$ & $M$ & EG & VP & $M$ & $M$ & $M$ & $M$ & $\mathrm{P}$ \\
\hline A2 & $\mathrm{P}$ & M & EG & VP & M & M & M & VP & EP \\
\hline A3 & $\mathrm{M}$ & $\mathrm{P}$ & $\mathrm{M}$ & $\mathrm{M}$ & $\mathrm{M}$ & $\mathrm{M}$ & $\mathrm{M}$ & EP & EP \\
\hline A4 & $\mathrm{M}$ & VG & $\mathrm{G}$ & $M$ & $\mathrm{M}$ & $M$ & $M$ & EP & VP \\
\hline A5 & VG & G & VG & $\mathrm{G}$ & MG & $\mathrm{G}$ & G & $\mathrm{P}$ & EP \\
\hline A6 & MG & EG & MG & $M$ & $\mathrm{M}$ & $\mathrm{M}$ & MG & EP & VP \\
\hline A7 & MG & EG & MG & $\mathrm{G}$ & $\mathrm{G}$ & MG & MG & EP & $\mathrm{P}$ \\
\hline A8 & MG & VG & EG & $\mathrm{G}$ & VG & VG & $\mathrm{G}$ & $G$ & EP \\
\hline
\end{tabular}

